\title{
The evaluation and optimal use of rituximab in lymphoid malignancies
}

This article was published in the following Dove Press journal:

Blood and Lymphatic Cancer:Targets and Therapy

30 December 2011

Number of times this article has been viewed

\author{
Tadeusz Robak' \\ Pawel Robak ${ }^{2}$ \\ Piotr Smolewski \\ 'Department of Hematology, \\ ${ }^{2}$ Experimental Hematology, Medical \\ University of Łódź, Łódź, Poland
}

Correspondence: Tadeusz Robak Department of Hematology, Medical University of Łódź, 93-5I0 Łódź, ul Ciołkowskiego 2, Poland Tel +04842689 I5 9l Fax +048426895192

Email robaktad@csk.umed.lodz.pl
Abstract: Rituximab is an $\operatorname{IgG} 1$, chimeric monoclonal antibody (mAb) containing murine light- and heavy-chain variable-region sequences and human constant-region sequences. Rituximab targets the CD20 molecule expressed on normal and malignant B-lymphocytes. At present, rituximab is the most important $\mathrm{mAb}$ of clinical value in patients with B-cell lymphoid malignancies. Since approval in 1997, rituximab has become widely used in chronic lymphocytic leukemia (CLL), follicular lymphoma (FL), mantle cell lymphoma (MCL), and diffused large B-cell lymphoma (DLBCL) when combined with chemotherapy. Currently, rituximab is commonly combined with first-line chemotherapy for FL and should be offered as maintenance therapy to all appropriate patients with this disease. Randomized Phase III trials demonstrated the superiority of rituximab added to CHOP chemotherapy against CHOP chemotherapy alone in patients with DLBCL. Rituximab alone has limited activity in MCL but can be used in MCL in combination with chemotherapy, despite the benefits not being as impressive as when used against other lymphoma entities. In addition, for the less frequent B-cell lymphomas, small series show considerable activity for most of these entities. Fludarabine and rituximab combination therapies in CLL yielded promising results in several studies. Two large Phase III randomized trials demonstrated the superiority of chemoimmunotherapy with rituximab compared with chemotherapy alone in previously untreated and refractory/relapsed patients with CLL. Therefore, it can be concluded that rituximab, with only few exceptions, can generally be accepted as a standard component of anti B-cell non-Hodgkin's lymphoma therapies. In this review, the pharmacology, mode of action, pharmacokinetics, and current place in the therapy of B-cell lymphoid malignancies of rituximab are presented. In addition, an overview of studies conducted to date and optimal use of this drug, including timing and doses, is presented.

Keywords: chronic lymphocytic leukemia, combined therapy, rituximab, DLBCL, follicular lymphoma, NHL, side effects, pharmacokinetics

\section{Introduction}

Lymphoid malignancies comprise a heterogeneous group of disorders originating from clonal proliferation of B or T lymphocytes. ${ }^{1}$ B-cell lymphoid malignancies are more common than T-cell neoplasms, accounting for approximately $85 \%-90 \%$ of all non-Hodgkin's lymphomas (NHL). ${ }^{2}$ The incidence of NHL has been increasing steadily over the past several decades. At present it is the fifth most common cancer in the US, with an estimated 66,360 new cases and 19,320 deaths. ${ }^{3}$ The most common subtypes of B-cell NHL are diffused large B-cell lymphoma (DLBCL) and follicular lymphoma (FL). ${ }^{4}$ DLBCL accounts for approximately $30 \%$ of all new diagnosed cases and more than $80 \%$ of aggressive lymphomas. FL is the second most common submit your manuscript | www.dovepress.com

Dovepress

http://dx.doi.org/10.2147/BLCTT.S1556|
Blood and Lymphatic Cancer:Targets and Therapy 2012:2 I-I6

(C) 2012 Robak et al, publisher and licensee Dove Medical Press Ltd. This is an Open Access article which permits unrestricted noncommercial use, provided the original work is properly cited. 
lymphoma, representing approximately $70 \%$ of all indolent lymphomas and $22 \%$ of all lymphomas. ${ }^{5}$ In addition, mantle cell lymphoma (MCL) is a distinct disease entity in the WHO classification of malignant neoplasms, and comprises $7 \%$ of NHLs. ${ }^{4}$

In DLBCL, the era of mAbs has transformed treatment practices and R-CHOP (rituximab plus cyclophosphamide, adriamycin, vincristin, prednisone) is now the new standard of care. ${ }^{6}$ Patients with FL can have long survival times, but disease progression typically occurs $3-5$ years after initial treatment, and there is no universally accepted standard front-line therapy. A broad range of therapeutic options is available, but historical studies have not shown a survival benefit of one regimen over another. However, the addition of rituximab to chemotherapeutic combinations (CVP cyclophosphamide, vincristin, prednisone; CHOP) has resulted in a significant increase in overall response (OR) rate, complete response $(\mathrm{CR})$ rate, and progression free survival (PFS). ${ }^{7}$

Chronic lymphocytic leukemia (CLL) is a clonal disease characterized by proliferation and accumulation of small CD5 positive B-cells. It is the most common form of leukemia in the Western world with an annual incidence rate of three to five cases per $100,000 .^{8}$ The management of CLL is determined by the stage, activity of the disease age, and comorbidities. For many years, chlorambucil has been the drug of choice in previously untreated patients with CLL. ${ }^{9,10}$ Subsequently, purine nucleoside analogs (PNAs) - fludarabine (FA), cladribine (2-CdA, 2-chlorodeoxyadenosine), and pentostatin (DCF, 2'-deoxycoformycin) have been introduced for the treatment of this disease and have become standard drugs for the majority of patients. Significantly higher OR, $\mathrm{CR}$, and a longer PFS in patients with CLL treated with FA or 2-CdA were confirmed in randomized, multicenter trials. ${ }^{11,12}$ Cyclophosphamide (CY) was the cytotoxic agent most frequently combined with PNA. The higher efficacy of FA combined with cyclophosphamide (FC) compared with FA alone was confirmed in randomized trials in treatment naïve patients. ${ }^{13}$ Cladribine combined with CY (CC) is similarly active in previously untreated CLL patients. ${ }^{14}$ Several randomized trials indicate that chemotherapy alone does not prolong the survival time of CLL patients. ${ }^{9-13}$ Several recent reports have suggested that in patients with CLL, rituximab combined with PNA, or PNA, and cyclophosphamide may improve the results with acceptable toxicity, both in previously untreated and refractory/relapsed patients. ${ }^{15,16}$ At present, rituximab is the most important monoclonal antibody (mAb) of clinical value in patients with B-cell lymphoid malignancies.

\section{Pharmacology and mode of action}

Rituximab (IDEC-C2B8; Mabthera ${ }^{\circledR}$, Roche, Basel, Switzerland; Rituxan ${ }^{\circledR}$, Biogen Idec, San Diego and Genentech, Inc, San Francisco, CA) is an IgG1, chimeric $\mathrm{mAb}$ containing murine light- and heavy-chain variable region sequences and human constant region sequences. Rituximab targets the CD20 molecule, expressed on normal and malignant B-lymphocytes. ${ }^{18}$ The variable murine region of rituximab binds specifically to the CD20 antigen. The CD20 (B1) antigen is a 33-35 kDa integral membrane protein expressed on the surfaces of non-malignant and most malignant $\mathrm{B}$ cells ${ }^{19}$ consisting of cytoplasmic N- and C-termini and four hydrophobic regions for anchoring the molecule in the membrane. Some evidence indicates that CD20 might function as a calcium ion channel. ${ }^{20}$ The intensity of CD20 antigen expression is lower on CLL cells than in patients with NHL and appears to correlate with the level of clinical response. ${ }^{21}$ The characteristics that make CD20 a good target antigen include its relatively high level of expression and close location of the extracellular epitopes to the cell surface. ${ }^{20}$ The CD20 circulating form has been detected in patients with CLL, Hodgkin's disease, and NHL, as well as in healthy individuals. ${ }^{22}$

\section{Mode of action}

The variable murine region of rituximab binds specifically to the CD20 antigen. The Fc domain recruits the immune effect or functions to mediate B-cell lysis. ${ }^{18,23}$ The antitumor activity of rituximab is attributed to complement dependent cytotoxicity (CDC), antibody-dependent cellular cytotoxicity (ADCC), apoptosis, and possible direct growth arrest. ${ }^{24-26} \mathrm{CDC}$ and $\mathrm{ADCC}$ are considered the main effects. CDC involves fixation of the complement by the Fc portion of immunoglobulin and the subsequent activation of the complement cascade. ${ }^{27,28}$

ADCC is positively regulated by activating Fc receptors that are expressed on NK cells, macrophages, and dendritic cells. These two mechanisms are categorized into "immunemobilizing" mechanisms or direct effects. It has been shown recently that human macrophages promote phagocytic killing of rituximab-opsonized CLL cells. In addition, accumulating evidence suggests that rituximab can also directly induce apoptosis. $^{29}$

Rituximab preferentially inhibits the expression of the antiapoptotic gene products Bcl-2/Bcl-xL, X-linked inhibitor of apoptosis protein, and myeloid cell leukemia sequence 1 in B-cell NHL cells through downregulating the p38 mitogenactivated protein kinase (MAPK), nuclear factor (NF)- $\mathrm{B}$, 
ERK-1/2, and Akt survival pathways. ${ }^{24}$ In addition, rituximab enhances apoptosis by a caspase-independent mechanism. ${ }^{30}$ Furthermore, rituximab sensitizes malignant B cells to the cytotoxic effects of chemotherapy. ${ }^{31}$

\section{Pharmacokinetics of rituximab}

Several studies have analyzed the pharmacokinetics (PK) of rituximab in patients receiving four or eight doses of the antibody for the treatment of active, relapsed, or refractory NHL. ${ }^{32,33}$ The results of these studies indicate that serum rituximab levels are highly variable in patients receiving similar doses. Rituximab pharmacokinetics are best described by a two-compartmental model, with mean half-lives of about 1.3 (distribution) and 19 days (elimination). ${ }^{17}$ In a pivotal trial, PK assessment of rituximab was performed in 147 patients with relapsed or refractory indolent NHL treated with 4 weekly infusions of rituximab at $375 \mathrm{mg} / \mathrm{m}^{2}{ }^{32,33}$ The rituximab level increased throughout the course of treatment, reaching mean concentrations of $206 \mu \mathrm{g} / \mathrm{mL}$ after the first infusion and $465 \mu \mathrm{g} / \mathrm{mL}$ after the fourth infusion. The estimated half-life of rituximab increased from 76.3 hours after the first infusion to 205.8 hours after the fourth infusion, with a concomitant marked decrease in the antibody clearance.

In another study, in which rituximab was given in four consecutive weekly doses of $375 \mathrm{mg} / \mathrm{m}^{2}$ to NHL patients, the serum concentration was seen to increase with each infusion from a median $\mathrm{C}_{\max }$ of $239 \mu \mathrm{g} / \mathrm{mL}$ after the first infusion to $460 \mu \mathrm{g} / \mathrm{mL}$ after the fourth one. ${ }^{34}$ Levels of the drug remained detectable in the serum for up to 3-6 months following completion of treatment. Serum rituximab levels have been shown to be proportional to the antibody dose infused. ${ }^{35}$ A receptor binding and saturation mechanism may be involved in the PK process. A study using noncompartmental analysis showed that from the first to the fourth infusion of rituximab, clearance decreased more than 4-fold and the half-life increased almost 3-fold in patients with NHL treated with weekly infusions of rituximab $375 \mathrm{mg} / \mathrm{m}^{2}{ }^{33}$ It is possible that these observations reflected depletion by rituximab of CD20-positive B-cells. ${ }^{32}$ In addition, higher and more sustained serum levels were achieved after multiple doses than after single doses. ${ }^{36}$ When the drug was administered at doses of $375 \mathrm{mg} / \mathrm{m}^{2}$ weekly for 8 weeks, the median post-infusion serum levels peaked higher than in studies using only four doses. ${ }^{37}$ However, a plateau was achieved after the sixth infusion. Moreover, higher mean serum antibody levels were observed in responders than in non-responders. ${ }^{33,34,38}$
The PK of rituximab have been characterized by wide inter-individual variability, with high serum drug concentrations appearing to correlate with the clinical response. In the study of Berinstein et al, ${ }^{33}$ patient serum rituximab levels correlated inversely with the degree of tumor bulk and the number of circulating B cells before treatment. In one study, steady-state plasma concentrations of rituximab were reached after 6-8 weekly infusions. ${ }^{39}$ However, in another study, Mangel et $\mathrm{al}^{40}$ found no differences in pharmacokinetic parameters between patients who were in clinical remission and historical controls treated with rituximab who exhibited a tumor burden. They also found that the level of rituximab exposure is similar after four infusions in patients treated for minimal disease states and patients with active disease. ${ }^{40}$ In addition, population pharmacokinetic studies by Regazzi et $\mathrm{al}^{39}$ showed that the PK characteristics of rituximab are similar for autoimmune disorders and relapsed or refractory FL or MCL. These results indicate that the PK profile of this drug does not necessarily correlate with disease burden. The PK studies should allow the best dosing regimen to be defined for the optimal efficacy of rituximab in an individual patient. ${ }^{41}$ Ternant et $\mathrm{al}^{42}$ used pharmacokinetic-pharmacodynamic (PK-PD) modeling to design an optimized rituximab dose regimen in FL patients. They suggest a benefit of increasing doses of rituximab in FL, both during induction and maintenance. The model predicted a potential benefit of $1500 \mathrm{mg} / \mathrm{m}^{2}$ maintenance doses of rituximab for both rituximab monotherapy and in R-CHOP combination. In addition, the authors have found that the PFS of FCGR3A-F carriers remains lower than that of homozygous FCGR3A-VV patients, even when higher rituximab doses were used. Few studies have investigated the pharmacokinetics of rituximab when administered with other drugs or at different intervals. ${ }^{42,43}$ The PK profile of rituximab when administered as part of an R-CHOP chemotherapy was recently reported by Blasco et al. ${ }^{44}$ They found that PK parameters were similar to those described for studies in the absence of chemotherapy. In addition, the authors did not observe any intra-subject variation in pharmacokinetic parameters over the treatment period. Rituximab is widely distributed to body organs, including heart, liver, lungs, spleen, and kidneys of patients with NHL.The drug is degraded in the liver and other organs by a process of nonspecific catabolism and is mainly excreted renally. ${ }^{45}$ The proportion of radiolabeled rituximab excreted in the urine was $47.5 \%{ }^{45}$

\section{Side effects}

Treatment with rituximab is usually well tolerated. However, infusion-related reactions occur in the majority of patients. 
These adverse effects are usually of mild or moderate severity, and only $10 \%$ of patients have shown a severe infusion-related reaction which may be accompanied by fever, bronchospasm, hypotension, and angioedema. The symptoms are usually brief and occur during the first infusion. ${ }^{46}$ Infusion-related adverse effects occur within the first 30 minutes to 2 hours of starting the first infusion, and are usually reversible with interruption or discontinuation of rituximab along with supportive care. In addition, patients may be susceptible to the development of human anti-mouse antibody (HAMA). However, in clinical practice HAMA and human anti-chimeric antibody are rarely detected. ${ }^{47}$

Several reports suggest that rituximab increases the risk of viral and bacterial infections due to prolonged impairment of antibody production. In a retrospective analysis of 215 NHL patients performed by Casulo et al, ${ }^{48}$ patients receiving rituximab maintenance had a significantly higher risk of developing hypogammaglobulinemia, and $10 \%$ required intravenous immune globulin infusion for infection. Recent data indicates that rituximab increases the risk of hepatitis $\mathrm{B}$ virus reactivation (HBV in patients with resolved infection). ${ }^{49-51}$ Elderly patients, particularly those without anti-HBs, seemed particularly at risk. However, the true incidence and mechanism of reactivation are still being elucidated and greater adherence to recommendations for screening and prophylaxis is necessary.

Problems with other viruses have also been reported in association with rituximab-containing regimens. Severe herpes virus reactivation including cytomegalovirus and varicella zoster has been reported in several patients. ${ }^{52}$ Some reports have indicated that Parvovirus B19 with pure red cell aplasia and West Nile virus may be linked to treatment with rituximab, ${ }^{53,54}$ in addition to progressive multifocal leukoencephalopathy (PML): ${ }^{55}$ a lethal, progressive demyelinating disorder of the central nervous system (CNS) characterized by the destruction of oligodendrocytes due to the reactivation of the John Cunningham (JC) virus (a type of human polyoma virus). A review of literature published recently revealed that 57 cases of rituximab-associated PML had been reported to date, mostly in patients who had lymphoproliferative disorders. ${ }^{56}$ Recent retrospective, monocentric cohort analysis indicates that inclusion of rituximab into standard chemotherapy regimens caused a significantly higher incidence of PML cases (rate difference, 2.2 every 1000 patient-years; 95\% confidence interval: $0.1-4.3) .{ }^{55}$ Importantly, a recent systematic review and meta-analysis of randomized controlled trials comparing rituximab combined with chemotherapy indicates that the addition of rituximab does not increase the overall risk of severe infections nor increases the risk of dying as a consequence of infection. ${ }^{57}$ However, the addition of rituximab to standard chemotherapy increases the risk of severe leukopenia and granulocytopenia.

\section{Overview of studies conducted to date in CLL and NHL}

Rituximab was the first mAb approved in 1997 by the Food and Drug Administration (FDA) for the treatment of FL. Since approval, rituximab has become the standard of care in FL, CLL, and aggressive lymphomas when combined with chemotherapy. In addition, for the less frequent B-cell lymphomas, small series show considerable effectiveness for most of these entities. Therefore it can be concluded that rituximab, with only few exceptions, can today be generally accepted as a standard component of anti B-cell non-Hodgkin lymphoma (B-NHL) therapies.

\section{Rituximab in follicular lymphoma}

There is no universally accepted standard frontline therapy for FL. A broad range of therapeutic options is available but historical studies have not shown a survival benefit of one regimen over another. However, the addition of rituximab to chemotherapeutic combinations (CHOP, CVP) has resulted in a significant increase in OR and CR rates, and time to progression (TTP). Rituximab in combination with chemotherapy improves PFS and OS compared to chemotherapy alone when used for induction therapy for patients with newly diagnosed or relapsed indolent lymphoma. ${ }^{58,59}$ Currently, an immunochemotherapy regimen based on a combination of rituximab with chemotherapy such as CHOP, CVP, or purine analog-based schemes should be applied in FL patients with progressive, symptomatic disease. ${ }^{60}$ In a large, randomized, multicenter study, the addition of rituximab to CVP (R-CVP) resulted in a significant increase in CR rate: $41 \%$ with rituximab versus $10 \%$ without. ${ }^{61}$

A number of promising trials have suggested that the addition of rituximab maintenance treatment after induction therapy might improve results in patients with FL. Induction therapies included chemotherapy alone, ${ }^{62}$ chemotherapy with rituximab, ${ }^{63,64}$ and rituximab alone (Table 1). ${ }^{65,66}$ These randomized trials documented longer PFS in patients receiving rituximab maintenance therapy. Unfortunately, these trials have failed to demonstrate a survival benefit with maintenance rituximab. A meta-analysis of randomized trials included 1143 adult patients with FL for response duration and 985 patients for overall survival. ${ }^{67}$ Previously treated patients had a survival benefit with riuximab 
Table I Trials of rituximab maintenance therapy in indolent lymphoma

\begin{tabular}{|c|c|c|c|c|c|c|c|}
\hline Study & No of pts & Type of lymphoma & $\begin{array}{l}\text { Induction } \\
\text { treatment }\end{array}$ & $\begin{array}{l}\text { Rituximab } \\
\text { maintenance }\end{array}$ & $\begin{array}{l}\text { Median } \\
\text { follow-up }\end{array}$ & $\begin{array}{l}\text { PFS } \\
\text { maintenance } \\
\text { vs control }\end{array}$ & $\begin{array}{l}\text { OS } \\
\text { maintenance } \\
\text { vs control }\end{array}$ \\
\hline Salles et a ${ }^{68}$ & 1217 & Untreated FL & $\begin{array}{l}\text { R-CHOP } \\
\text { R-CVP } \\
\text { R-FCM }\end{array}$ & $\begin{array}{l}\text { A single infusion } \\
\text { every } 8 \text { wk for } 4 \text { y }\end{array}$ & $36 \mathrm{~m}$ & $\begin{array}{l}74.9 \% \text { vs } \\
57.6 \% \\
P<0.000\end{array}$ & $\begin{array}{l}26 \text { deaths vs } 30 \\
\text { deaths } \\
P=N S\end{array}$ \\
\hline Hochster et al ${ }^{62}$ & $311 *$ & Untreated FL, SLL & CVP & $\begin{array}{l}\text { Weekly for } 4 \mathrm{wk} \\
\text { every } 6 \mathrm{~m} \text { for } 2 \mathrm{y}\end{array}$ & $3.7 y$ & $\begin{array}{l}68 \% \text { vs } 33 \% \\
P=0.4\end{array}$ & $\begin{array}{l}92 \% \text { vs } 86 \% \\
P=0.05\end{array}$ \\
\hline van Oers et $\mathrm{al}^{63}$ & 465 & Relapsed/resistant FL & $\begin{array}{l}\text { CHOP vs } \\
\text { R-CHOP }\end{array}$ & $\begin{array}{l}\text { A single infusion } \\
\text { every } 3 \mathrm{~m} \text { for } 2 \mathrm{y}\end{array}$ & $6 y$ & $\begin{array}{l}3.7 \text { y vs } 1.3 \text { y } \\
P<0.00 \mathrm{I}\end{array}$ & $\begin{array}{l}5-y \text { OS } \\
74 \% \text { vs } 64 \% \\
P=0.07\end{array}$ \\
\hline Forstpointner et $\mathrm{al}^{164}$ & $195 * *$ & Relapsed FL, MCL & $\mathrm{FCM} \pm \mathrm{R}$ & $\begin{array}{l}\text { Weekly for } 4 \mathrm{wk} \\
\text { at } 3 \text { and } 9 \mathrm{~m}\end{array}$ & $26 \mathrm{~m}$ & $\begin{array}{l}\text { Median not } \\
\text { reached vs } 17 \mathrm{~m} \\
P<0.00 \text { I }\end{array}$ & $\begin{array}{l}3-y \text { OS } \\
77 \% \text { vs } 57 \% \\
P=0.1\end{array}$ \\
\hline Ghielmini et al ${ }^{65}$ & 185 & Untreated/relapsed FL & Rituximab & $\begin{array}{l}\text { A single infusion } \\
\text { every } 2 \mathrm{~m} \text { for } 4 \\
\text { doses }\end{array}$ & $35 \mathrm{~m}$ & $\begin{array}{l}\text { EFS: } \\
23 \mathrm{~m} \text { vs } 12 \mathrm{~m} \\
P=0.02\end{array}$ & NR \\
\hline Hainsworth et al ${ }^{66}$ & 114 & $\begin{array}{l}\text { Previously treated } \\
\text { FL, SLL }\end{array}$ & Rituximab & $\begin{array}{l}\text { Weekly for } 4 \text { wk } \\
\text { every } 6 \mathrm{~m} \text { for } 2 y\end{array}$ & $41 \mathrm{~m}$ & $\begin{array}{l}31.3 \mathrm{~m} \text { vs } 7.4 \mathrm{~m} \\
P=0.007\end{array}$ & $\begin{array}{l}3-y \text { OS } \\
72 \% \text { vs } 68 \%\end{array}$ \\
\hline
\end{tabular}

Notes: *FL-282pts; **FL-II 3pts, MCL-57pts.

Abbreviations: FL, follicular lymphoma; SLL, small lymphocytic lymphoma; MCL, mantle cell lymphoma; CHOP, cyclophosphamide, doxorubicin, vincristin, prednisone; CVP, cyclophosphamide, vincristin, prednisone; FCM, fludarabine, chlorambucil, mitoxantrone; R, rituximab; m, months; y, years; wk, weeks; NS, no significent changes; NR, not reported.

maintenance treatment (hazard ratio: 0.58). Recently Salles et $\mathrm{l}^{68}$ evaluated maintenance treatment with rituximab in patients with FL after first-line therapy with rituximab and chemotherapy regimens. This multicenter study, known as PRIMA, included 1217 patients with grade 1, 2, or 3A FL needing systemic therapy. They received one of three non-randomized immunochemotherapy induction regimens used in routine practice. Patients who obtained CR or PR were then randomly assigned to receive either rituximab maintenance therapy at a dose of $375 \mathrm{mg} / \mathrm{m}^{2}$ every 8 weeks or observation. With a median follow-up of 36 months, the primary study endpoint, PFS from randomization, and time to next anti-lymphoma treatment were significantly longer in patients who received maintenance therapy with rituximab in comparison with the observation-only group. However, OS did not differ significantly between groups.

\section{Diffuse large B-cell lymphoma}

Rituximab was originally used in relapsed/refractory DLBCL patients in monotherapy in a Phase II clinical trial. ${ }^{69}$ Subsequently, several multicenter clinical trials have documented that the addition of rituximab to a standard CHOP regimen (R-CHOP) increases the efficacy of this first-line treatment, both in older $(>60 \text { years })^{70,71}$ and younger ${ }^{72}$ DLBCL patients (Table 2). Firstly, Vose et $\mathrm{al}^{74}$ showed that six cycles of R-CHOP resulted in $89 \%$ of OR, including $56 \%$ CR. Subsequently, a randomized Phase III trial of GELA (Groupe d'Etudes des Lymphomes de l'Adulte) assessed the effectiveness of eight courses of R-CHOP vs the same number of CHOP regimens in elderly DLBCL patients. Both R-CHOP and CHOP were given every 21 days. Patients treated with R-CHOP demonstrated a better OS than those from the CHOP arm (median OS not reached after 5 years, vs 3.1 years, $P=0.007) .{ }^{70}$ The CR rates and PFS were also higher in R-CHOP treated patients ( $76 \%$ vs $63 \%$ and 3.8 years vs 1.1 years, respectively). A further study, MInT (Mabthera International Trial), was addressed to low-risk DLBCL patients, younger than those in the GELA trial. ${ }^{73,75}$ As in the GELA trial, they were randomly treated with either CHOPlike or R-CHOP-like regimens. Patients in the R-CHOP arm showed higher 3-year EFS (79\% vs 59\%, $P<0.0001)$ and, most importantly, OS (93\% vs $84 \%, P=0.0001)$.

Ongoing studies assess the effects of R-CHOP given every 14 days (R-CHOP-14) and every 21 days (R-CHOP-21). In the RICOVER-60 trial, Pfreundschuh et al $^{72}$ compared CHOP-14 and R-CHOP-14 regimens in elderly patients with DLBCL. The R-CHOP-14 program showed advantage over CHOP-14 in regard to PFS and OS. Eight courses of R-CHOP-14 did not improve the outcome (namely, 3-year EFS) compared to six cycles of this regimen ( $66.5 \%$ vs $63 \%$, respectively). Moreover, any statistical advantage of R-CHOP-21 vs R-CHOP-14 was shown in elderly DLBCL patients.

High-dose chemotherapy (HDC) with autologous stem cell transplantation (ASCT) is actually a standard of care in the case of younger patients with relapsed/refractory DLBCL. ${ }^{76}$ There are few non-randomized studies on the 
Table 2 Larger studies evaluating the efficacy of rituximab combined with first-line treatment or salvage chemotherapy in patients with DLBCL

\begin{tabular}{|c|c|c|c|c|c|c|}
\hline Study & Treatment & Patients & OR & CR & $\begin{array}{l}\text { Median TTF/PFS/ } \\
\text { EFS }\end{array}$ & OS \\
\hline $\begin{array}{l}\text { Pfreundschuh } \\
\text { et } \mathrm{al}^{72}\end{array}$ & $\begin{array}{l}6 \text { vs } 8 \times \\
\text { R-CHOP-I } 4 \pm R\end{array}$ & $\begin{array}{l}\text { Untreated } \\
n=1222 \\
\text { age } 61-80\end{array}$ & $\begin{array}{l}76 \% \text { vs } 63 \% \\
P=0.005\end{array}$ & NR & $\begin{array}{l}3 \text {-year EFS: } \\
6 \times \text { CHOP-I } 4 \text { vs } \\
8 \times \text { CHOP } \\
47.2 \% \text { vs } 53 \% \\
6 \times \text { CHOP-I } 4 \text { vs } \\
8 \times \text { R-CHOP } \\
66.5 \% \text { vs } 63.1 \%\end{array}$ & $\begin{array}{l}\text { 3-year OS: } \\
6 \times \text { CHOP- } 14 \text { vs } 8 \times C H O P \\
67.7 \% \text { vs } 66.0 \% 6 \times \text { CHOP- } \\
14 \text { vs } 8 \times \text { R-CHOP } \\
78.1 \% \text { vs } 72.5 \%\end{array}$ \\
\hline $\begin{array}{l}\text { Coiffier } \\
\text { et al }{ }^{70}\end{array}$ & $\begin{array}{l}8 \times \mathrm{R}-\mathrm{CHOP} \text { vs } \\
8 \times \mathrm{CHOP}\end{array}$ & $\begin{array}{l}\text { Untreated } \\
\mathrm{n}=399 \\
\text { age } 60-80\end{array}$ & $\begin{array}{l}82 \% \text { vs } 69 \% \\
P<0.05\end{array}$ & $\begin{array}{l}72 \% \text { vs } 37 \% \\
P=0.005\end{array}$ & $\begin{array}{l}\text { EFS: } \\
3.8 \text { vs I.I years } \\
P<0.001\end{array}$ & $\begin{array}{l}\text { Median OS not reached } \\
\text { after } 5 \text { years vs } 3.1 \text { years } \\
P=0.007\end{array}$ \\
\hline $\begin{array}{l}\text { Pfreundschuh } \\
\text { et } \mathrm{al}^{73,75}\end{array}$ & $\begin{array}{l}6 \times \mathrm{CHOP} \text {-like vs } \\
6 \times \mathrm{R} \text {-CHOP-like }\end{array}$ & $\begin{array}{l}\text { Untreated } \\
n=824 \\
\text { age } 18-60\end{array}$ & NR & NR & $\begin{array}{l}3 \text {-year EFS: } \\
79 \% \text { vs } 59 \% \\
P<0.000 \text { I } \\
6 \text {-year EFS } \\
56 \% \text { vs } 74 \% \\
P<0.0001\end{array}$ & $\begin{array}{l}\text { 3-year OS: } \\
93 \% \text { vs } 84 \% \\
P=0.00001\end{array}$ \\
\hline $\begin{array}{l}\text { Kewalramani } \\
\text { et } \mathrm{al}^{77}\end{array}$ & $\begin{array}{l}\text { R-ICE vs historical } \\
\text { ICE cohort }\end{array}$ & $\begin{array}{l}\text { Relapsed/ } \\
\text { refractory } \\
n=36 \text { vs I } 47 \\
\text { median age } \\
45 \text { vs } 48\end{array}$ & $\begin{array}{l}78 \% \text { vs } 71 \% \\
P=0.53\end{array}$ & $\begin{array}{l}53 \% \text { vs } 27 \% \\
P=0.01\end{array}$ & $\begin{array}{l}\text { PFS at } 2 \text { years } \\
54 \% \text { vs } 43 \%\end{array}$ & $\begin{array}{l}\text { OS after } 2 \text { years } \\
67 \% \text { vs } 56 \% \\
\text { (ns) }\end{array}$ \\
\hline $\begin{array}{l}\text { Habermann } \\
\text { et } \mathrm{al}^{71}\end{array}$ & $\begin{array}{l}\text { R-CHOP vs CHOP, } \\
\text { then R-maintenance } \\
\text { (MR) or } \\
\text { observation }(\mathrm{O})\end{array}$ & $\begin{array}{l}\text { Untreated } \\
n=632\end{array}$ & NR & NR & $\begin{array}{l}\text { 3-year FFS: } \\
\text { R-CHOP vs CHOP } \\
53 \% \text { vs } 46 \% \\
P=0.04 \\
\text { 2-year FFS: } \\
\text { MR vs } O \\
76 \text { vs } 61 \% \\
P=0.009\end{array}$ & $\begin{array}{l}3 \text {-year OS } \\
\text { R-CHOP vs CHOP } \\
67 \% \text { vs } 57 \% \\
P=0.05\end{array}$ \\
\hline
\end{tabular}

Abbreviations: DLBCL, diffuse large B-cell lymphoma; PFS, progression free survival; TTF, time to treatment failure; NR, not reported; ns, no significant differences; R, rituximab; CHOP, cyclophosphamide, doxorubicin, vincristine, and prednisolone; ICE, ifosfamide, carboplatin, etoposide; EFS, event-free survival; HDS, high-dose sequential chemotherapy regimen; MR, maintenance; O, observation arm; OS, overall survival.

role of rituximab combined with salvage HDC regimens, based on comparisons with historical cohorts of patients. Kewalramani et $\mathrm{al}^{77}$ reported an improvement of CR rates after R-ICE (rituximab, ifosfamide, carboplatin, etoposide), when compared to patients treated with ICE only (53\% vs $27 \%$, respectively). PFS after 2 years was slightly better in patients treated with ASCT after R-ICE (54\% vs 43\%). An R-DHAP (rituximab, dexamethasone, cytarabinoside, cisplatin) regimen generated higher overall response rate (ORR) than in DHAP treated patients (63\% vs 42\%). PFS at 2 years and OS were significantly better with R-DHAP receiving patients than in the historical DHAP treated group (57\% vs $18 \%$ and $77 \%$ vs $37 \%$, respectively). ${ }^{78}$ Moreover, rituximab in combination with a DexaBEAM regimen (dexamethason, BCNU, etoposide, cytarabinoside, melphalan) and further conditioning treatment with BEAM or total body irradiation and cyclophosphamide (TBI/Cy) was distinctly better than in patients without rituximab, with an OS after 4.5 years in the rituximab group ( $67 \%$ vs $45 \%$ in historical control). ${ }^{79}$ The CORAL (Collaborative trial in Relapsed Aggressive Lymphoma) study is the first randomized trial comparing the activities of the R-ICE and R-DHAP regimens as a HDC before ASCT, however, the final results are still not yet available. ${ }^{80}$ Recently, Tarella et $\mathrm{al}^{81}$ showed the advantage of a combination of rituximab with HDC administered prior to ASCT in regard to OS (64\% in patients with R-HDC vs $38 \%$ in HDC group).

Habermann et al, ${ }^{71}$ studying the role of rituximab in DLBCL maintenance after first-line treatment, showed that only CHOPtreated patients benefited from the maintenance in regard to PFS. The final results of the CORAL trial concerning the role of rituximab maintenance after ASCT are yet to be known.

\section{Mantle cell lymphoma}

Rituximab has been studied both in combination with existing chemotherapeutic regimens and as monotherapy 
in the treatment of MCL (Table 3). A study by Ghelmini et $\mathrm{al}^{82}$ showed that rituximab as a single agent had rather low activity in MCL. The OR of 88 analyzed patients was $27 \%$, including CR in $2.3 \%$ of the study group. The duration of remission was only 6-12 months. In 2005, the German Low Grade Lymphoma Study Group (GLSG) conducted a randomized trial comparing $\mathrm{R}-\mathrm{CHOP}$ and $\mathrm{CHOP}$ in first-line therapy. ${ }^{83}$ In the cohort of 122 MCL patients, OR was found to be better in the R-CHOP group (94\% vs $75 \%$ in CHOP arm; $P=0.0054)$. Also the $\mathrm{CR}$ rate and median time to treatment failure (TTF) were better in R-CHOP patients (34\% vs $7 \%, P=0.0002$ and 21 vs 14 months, respectively). However, no difference was found in regard to both PFS and OS.

The combination of rituximab with a hyper-CVAD regimen (three cycles high dose methotrexate and cytarabinoside alternating with three cycles cyclophosphamide, vincristine, doxorubicin, and dexamethasone), produced a longer PFS after 3 years $(64 \%)$ than hyper-CVAD only. ${ }^{84}$ The OR was $97 \%$, including $87 \%$ of CR. As a matter of fact, the benefit of rituximab on OS in MCL patients was indicated by the results of a meta-analysis by Schultz et al. ${ }^{85}$ This analysis included data from three separate trials ${ }^{83,86}$ with a total cohort of $260 \mathrm{MCL}$ patients. In this meta-analysis, the hazard ratio for death was 0.6 , which indicated a significant advantage for patients receiving rituximab plus chemotherapy, compared to chemotherapy alone.

Additionally, indirect evidence of a survival benefit for rituximab in MCL comes from a historical comparison of patients treated by CLSG with patients treated by the Kiel Lymphoma Study Group (KLSG). ${ }^{87}$ The GLSG patients were treated with MCP (mitoxantrone, chlorambucil, prednisone), CHOP, or R-CHOP regimens, whereas KLSG patients received either COP or CHOP. Patients from those two groups were matched and the OS was compared. The median OS rate was 2.7 years in the KLSG study compared to 4.8 years in the GLSG study $(P<0.0001)$, and the 5-year survival rates were $22 \%$ and $47 \%$, respectively. However, the only already published randomized trial on combined rituximab-chemotherapy regimens in previously untreated patients with MCL showed no difference in OS, with a 2-year probability of $76.6 \%$ OS $(P>0.05$ for the difference between the two groups). ${ }^{83}$ On the other hand, the addition of rituximab to chemotherapy alone as first-line therapy was found to improve OS in elderly patients with MCL in an analysis recently published by Griffiths et al. ${ }^{88}$ Median OS was 27 months for chemotherapy alone compared to 37 months for rituximab combined with first-line regimens $(P<0.001)$. Hence, it seems that first-line chemotherapy

Table 3 Larger studies evaluating the efficacy of rituximab combined with first-line treatment or salvage chemotherapy in patients with mantle cell lymphoma

\begin{tabular}{|c|c|c|c|c|c|c|}
\hline Study & Treatment & Patients & OR & CR & Median TTF/PFS & OS \\
\hline $\begin{array}{l}\text { Lentz et al } \\
(\text { GLSG })^{83}\end{array}$ & $\mathrm{R}-\mathrm{CHOP}$ vs $\mathrm{CHOP}$ & $\begin{array}{l}\text { Untreated } \\
\mathrm{n}=122\end{array}$ & $\begin{array}{l}94 \% \text { vs } 75 \% \\
P=0.0054\end{array}$ & $\begin{array}{l}34 \% \text { vs } 7 \% \\
P=0.00024\end{array}$ & $\begin{array}{l}\text { TTF }-21 \text { vs } 14 \text { months } \\
P=.0131 \\
\text { PFS } \\
\text { ns }\end{array}$ & ns \\
\hline $\begin{array}{l}\text { Romaguera } \\
\text { et } \mathrm{al}^{84}\end{array}$ & R-hyper-CVAD/HDMC & $\begin{array}{l}\text { Untreated } \\
\mathrm{n}=97\end{array}$ & $97 \%$ & $87 \%$ & $\begin{array}{l}\text { At } 10 \text { years of follow- } \\
\text { up (median } 8 \text { years), } \\
\text { TTF - } 4.6 \text { years }\end{array}$ & $\begin{array}{l}\text { At } 10 \text { years of follow-up (median } \\
8 \text { years), OS for all patients had } \\
\text { not been reached }\end{array}$ \\
\hline $\begin{array}{l}\text { Griffiths } \\
\text { et } a^{88}\end{array}$ & $\begin{array}{l}\text { R-CHOP/R-CHOP-like } \\
\text { vs CHOP/CHOP-like }\end{array}$ & $\begin{array}{l}\text { Untreated } \\
\mathrm{n}=638 \\
\text { median age } \\
75 \text { years }\end{array}$ & NR & NR & NR & $\begin{array}{l}37 \text { months for chemotherapy } \\
\text { alone vs } 27 \text { months for } R \\
\text { combined with first-line regimens } \\
P<0.00 \text { I }\end{array}$ \\
\hline $\begin{array}{l}\text { Forstpointer } \\
\text { et } \mathrm{al}^{89}\end{array}$ & R-FCM vs FCM & $\begin{array}{l}\text { Relapsed/ } \\
\text { refractory } \\
n=48\end{array}$ & $\begin{array}{l}58 \% \text { vs } 46 \% \\
\text { ns }\end{array}$ & $\begin{array}{l}13 \% \text { vs } 0 \% \\
P<0.0 \mid\end{array}$ & $\begin{array}{l}\text { PFS } 8 \text { vs } 4 \text { months } \\
P=0.389\end{array}$ & $\begin{array}{l}\text { Median OS R-FCM was not } \\
\text { reached; for FCM - II months } \\
P=0.042\end{array}$ \\
\hline $\begin{array}{l}\text { Forstpointer } \\
\text { et } \mathrm{al}^{92}\end{array}$ & $\begin{array}{l}\text { R-FCM vs FCM } \\
\text { maintenance (MR) }\end{array}$ & $\begin{array}{l}\text { Relapsed/ } \\
\text { refractory } \\
\text { FCM vs R-FCM } \\
n=50 \\
\text { MR } n=57 \\
\text { median age } 62\end{array}$ & $\begin{array}{l}46 \% \text { vs } 58 \% \\
\text { ns }\end{array}$ & $29 \%$ vs $0 \%$ & $\begin{array}{l}\text { Alive at } 3 \text { years } \\
\text { I } 4 \text { vs } 12 \text { months } \\
P=0.049 \\
\text { Remissions beyond } \\
2 \text { years } 45 \% \text { vs } 9 \%\end{array}$ & $\begin{array}{l}\text { Median OS for RCM not } \\
\text { reached. The estimated } \\
\text { proportion of patients alive at } \\
3 \text { years is } 77 \% \text { after MR vs } 57 \% \\
\text { with } O P=0.100\end{array}$ \\
\hline
\end{tabular}

Abbreviations: GLSG, German Lymphoma Study Group; PFS, progression free survival; TTF, time to treatment failure; ns, no significant differences; R, rituximab; CHOP, cyclophosphamide, adriamycin, vincristine, prednisone; OR, overall response; CR, complete response; PFS, progression free survival; TFS, treatment-free survival; OS, overall survival; hyper-CVAD /HDMC regimen, 3 cycles cyclophosphamide, vincristine, doxorubicin and dexamethasone alternating with 3 cycles high dose methotrexate and cytarabinoside; MCP, mitoxantrone, chlorambucil, prednisone; KLSG, Kiel Lymphoma Study Group; FCM, fludarabine, cyclophosphamide, mitoxantrone; FL, follicular lymphoma; MR, rituximab maintenance; O, observation only group; CHOP, cyclophosphamide, doxorubicin, vincristine, and prednisolone; FCM, fludarabine, cyclophosphamide, mitoxantrone; NR, not reported. 
including rituximab is associated with significantly improved survival in older patients diagnosed with MCL.

In a randomized study by GLSG, a combination of rituximab with the FCM (fludarabine, cyclophosphamide, mitoxantrone) regimen was examined in comparison with FCM in relapsed/refractory patients with MCL. ${ }^{89}$ R-FCM showed a distinct OR improvement compared to FCM (58\% vs $46 \%$ ), however the CR rates were low in both treatment arms (13\% vs $0 \%)$. However, the R-FCM regimen led to significantly prolonged PFS and OS after 2 years (8 vs 4 months and $65 \%$ vs $35 \%$, respectively). Hoerr et $\mathrm{al}^{90}$ assessed the activity of treatment after addition of rituximab to the salvage HDC scheme, showing a significant benefit with regard to PFS and OS. In another study, a combination of rituximab with TBI/Cy, applied prior to alloSCT, improved EFS (median not reached vs 43 months in no rituximab group) and OS after 4 years (87\% vs $77 \%$, respectively)..$^{91}$

Rituximab in maintenance therapy was assessed in a trial of the GLSG. MCL patients randomly treated with R-FCM vs FCM regimens with rituximab maintenance showed a benefit of maintenance. ${ }^{92}$ Although the median response duration did not differ between rituximab maintenance and observation only (14 vs 12 months), a higher proportion of patients in this evaluation experienced ongoing remissions beyond 2 years ( $45 \%$ vs $9 \%)$.

\section{Rituximab in CLL}

When used as a single agent at a dose of $375 \mathrm{mg} / \mathrm{m}^{2}$, Rituximab demonstrated limited activity in previously treated CLL. ${ }^{92,93}$ However, in a study performed by O'Brian et al, ${ }^{94}$ a correlation was found between the dose of rituximab and the clinical response. In this trial, CLL patients received an initial dose of rituximab of $375 \mathrm{mg} / \mathrm{m}^{2}$ which was then increased to a fixed dose of between 500 and $2250 \mathrm{mg} / \mathrm{m}^{2}$ once weekly for 4 weeks. The OR rate was $36 \%$ and ranged between $22 \%$ for lower doses and $75 \%$ for the highest doses. Byrd et al reported a dose-dense (thrice weekly) rituximab study in 83 previously treated CLL patients. The patients received different doses of rituximab $\left(250-375 \mathrm{mg} / \mathrm{m}^{2}\right)$ three times weekly for 4 weeks. ${ }^{95}$ The OR rate was $45 \%$ including $3 \% \mathrm{CR}$ and $42 \%$ PR. Single-agent rituximab was also evaluated in patients with previously untreated CLL. In the study performed by Hainsworth et al, ${ }^{96} 44$ previously untreated, symptomatic patients received four weekly doses of rituximab $375 \mathrm{mg} / \mathrm{m}^{2}$. The OR rate was 51\% and CR 4\%. Recently, Ferrajoli et al ${ }^{97}$ reported the results of an early intervention with standarddose rituximab $\left(375 \mathrm{mg} / \mathrm{m}^{2}\right.$ intravenously weekly for 8 consecutive weeks) in 34 asymptomatic, untreated, early-stage
CLL patients. The OR rate in 34 patients was $82 \%$ including $9 \%$ CR. Median time to progression (TTP) in the 28 responders was 23 months and the 8 -year OS rate was $74 \%$. Although rituximab is active as a single agent, responses are poorer than in other B-cell NHL.

Fludarabine and rituximab combination therapies in CLL yielded promising results in several studies, both in previously treated and untreated patients (Tables 4 and 5). Several studies indicated that adding rituximab to FA (FR) in the initial treatment of CLL may produce an increase in the CR rate. ${ }^{98-100}$ Del Poeta et al $^{99}$ conducted a Phase II study in which FR was given to the patients with symptomatic, untreated CLL. Sixty patients with CLL received 6-monthly courses of FA (25 mg/ $\mathrm{m}^{2}$ for 5 days) followed by 4-weekly doses of rituximab $\left(375 \mathrm{mg} / \mathrm{m}^{2}\right)$. Forty-seven of 60 patients $(78 \%)$ achieved CR and nine of 60 patients (15\%) achieved PR.

Similar results were reported by Byrd et al ${ }^{98,101}$ from the Cancer and Leukemia Group B (CALGB). In this randomized study, patients received either 6-monthly courses of rituximab concurrently with FA, followed 2 months later by 4-weekly doses of rituximab for consolidation therapy, or sequential FA alone, followed 2 months later by rituximab alone for consolidation. In the concurrent regimen, the OR was $90 \%$ with a $47 \%$ CR compared with a $77 \%$ OR and $28 \%$ CR in the sequential regimen. Subsequently, this group retrospectively compared the treatment outcome of patients treated with FR or FA alone enrolled on two multicenter clinical trials performed by the CALGB and the US Intergroup. In this study, patients were treated with FR (CALGB 9712, $\mathrm{n}=104$ ) or FA alone (CALGB 9011, $\mathrm{n}=178$ ). In multivariate analyses, the patients receiving FR had a significantly better PFS and OS than patients receiving FA alone. Subsequently, the authors reported the updated results of the CALGB 9712 trial with a median follow-up of 117 months. ${ }^{102}$ The median PFS was 42 months, and $27 \%$ of the patients were progression free at 5 years. The median OS was 85 months, and $71 \%$ of patients were alive at 5 years.

Recently, Gerrie et al $^{103}$ reported the results of treatment with oral FA combined with rituximab as frontline treatment of CLL in a community-based setting. Ninety-eight patients received FR for CLL/SLL from 2004 to 2009. Two- and 4-year treatment-free survival (TFS) was 69\% and 54\% (median 4.0 years). Two- and 4 -year OS was $90 \%$ and $73 \%$, respectively (median not reached). These results indicate that FR with oral fludarabine can be successfully given to community-based patients and is more convenient than R-FC with intravenous FA. 
Table 4 Larger studies evaluating the efficacy of rituximab combined with fludarabine \pm cyclophosphamide in previously untreated patients with CLL

\begin{tabular}{|c|c|c|c|c|c|c|}
\hline Study & Treatment & No of patients & Median age & OR & CR & Median PFS \\
\hline Schulz et al $\left.\right|^{100}$ & $R-F$ & 20 & 59 & $85 \%$ & $20 \%$ & 75 weeks \\
\hline Woyach et al ${ }^{104}$ & $\mathrm{R}-\mathrm{F}$ & 104 & 63 & $\begin{array}{l}84 \% \\
(77 \% * \text { and } 90 \% * *)\end{array}$ & $\begin{array}{l}28 \% * \text { and } \\
47 \% * *\end{array}$ & 42 months \\
\hline Gerrie et al $^{103}$ & $\mathrm{R}-\mathrm{F} * * *$ & 98 & 62 & NR & $N R$ & TFS -4 years \\
\hline Keating et al ${ }^{106}$ & R-FC & 224 & 58 & $95 \%$ & $70 \%$ & NR \\
\hline Hallek et al ${ }^{15}$ & R-FC & 408 & 61 & $90 \%$ & $44 \%$ & 58.1 months \\
\hline Foon et al ${ }^{108}$ & R-FC lite & 48 & 58 & $100 \%$ & $79 \%$ & $\begin{array}{l}22+\text { months } \\
\text { for } C R\end{array}$ \\
\hline Faderl et al ${ }^{\prime \prime \prime}$ & R-FCM & 30 & 57 & $96 \%$ & $83 \%$ & $\begin{array}{l}\text { Median PFS } \\
\text { not reached }\end{array}$ \\
\hline Bosch et $\mathrm{al}^{1 / 2}$ & R-FCM & 72 & 60 & $93 \%$ & $82 \%$ & $N R$ \\
\hline Parikh et al ${ }^{115}$ & CFAR & 60 & 59 & $92 \%$ & $70 \%$ & 38 months \\
\hline
\end{tabular}

Notes: *R and $\mathrm{F}$ administered sequentially; $* * \mathrm{R}$ and $\mathrm{F}$ administered concurrently; ***oral $\mathrm{F}$.

Abbreviations: NR, not reported; F, fludarabine; C, cyclophosphamide; R, rituximab; M, mitoxantrone; B, bendamustin; A, alemtuzumab; HDMP, high-dose methylprednisolone; OR, overall response; CR, complete response; PFS, progression free survival; TFS, treatment-free survival.

The combination of rituximab with FC (R-FC regimen) demonstrated particularly high rates of OR, CR, and duration of PFS in relapsed/refractory and previously untreated patients with CLL (Table 1). ${ }^{16,104}$ Wierda et al ${ }^{105}$ evaluated the efficacy, toxicity, and tolerability of R-FC in patients with previously treated CLL. CR was achieved in $25 \%$ of 177 patients and the OR rate was $73 \%$. In $12(32 \%)$ of 37 patients with $\mathrm{CR}$, molecular remission in the bone marrow was noted. Prospective, randomized study have recently confirmed the advantage of the R-FC regimen over the FC regimen in previously treated, relapsed, or refractory patients (REACH study). ${ }^{106}$ The primary endpoint of the study, PFS, was prolonged by 10 months in the R-FC arm (30.6 months) compared to FC (20.6 months, $P=0.0002)$.

Keating et al ${ }^{106}$ evaluated R-FC regimen as front-line therapy in 224 patients with progressive or advanced CLL. The $\mathrm{CR}$ rate was $70 \%$ and the OR was $95 \%$. Moreover, preliminary analysis suggested that chemotherapy with R-FC improved PFS and OS. These results were subsequently confirmed by the German CLL study group (GCLLSG) in a randomized, multicenter, multinational Phase III trial. ${ }^{15}$ In this study, 817 previously untreated, physically fit patients were randomly assigned to receive six courses of either FC or R-FC. At 3 years after randomization, $65 \%$ of patients in the R-FC group were free of progression compared with $45 \%$ in the FC group $(P<0.0001)$. At the same time, $87 \%$ were alive versus $83 \%$, respectively $(P=0.01)$. However, R-FC treatment was more frequently associated with grade 3 and 4 neutropenia ( $34 \%$ vs $21 \% ; P<0.0001$ ). Retrospective analysis performed by Tsimberidou et al ${ }^{107}$ indicated that chemoimmunotherapy with R-FC may overcome the adverse prognostic significance of $11 \mathrm{q}$ deletion in previously untreated patients with CLL. Currently, R-FC is becoming the first-line choice for younger, physically fit patients with CLL. Reducing the doses of FA and CY while increasing the dose of rituximab demonstrated good efficacy combined with improved tolerability in previously untreated CLL patients. ${ }^{108}$

Addition of a fourth drug to the R-FC immunochemotherapy of CLL could further improve the treatment outcome. ${ }^{109}$

Table 5 Larger studies evaluating the efficacy of rituximab combined with fludarabine \pm cyclophosphamide in previously treated patients with CLL

\begin{tabular}{|c|c|c|c|c|c|c|c|}
\hline Study & Treatment & No of patients & $\begin{array}{l}\text { Median } \\
\text { age }\end{array}$ & $\begin{array}{l}\text { No of previous } \\
\text { treatments }\end{array}$ & OR & CR & PFS \\
\hline Schulz et $\left.a\right|^{85}$ & $\mathrm{R}-\mathrm{F}$ & II & 59 & $\mathrm{I}-4$ & $90 \%$ & $27 \%$ & 75 weeks \\
\hline Wierda et al ${ }^{105}$ & R-FC & 179 & 59 & 2 & $73 \%$ & $25 \%$ & 28 months \\
\hline Robak et al ${ }^{16}$ & $\mathrm{R}-\mathrm{FC}$ & 276 & 63 & I & $69.9 \%$ & $24.3 \%$ & 30.6 months \\
\hline Byrd et al ${ }^{1 / 3}$ & $\mathrm{FCR}+\mathrm{L}$ & 31 & 58 & 2 & $65 \%$ & $52 \%$ & 29 months \\
\hline Badoux et al ${ }^{1 / 4}$ & CFAR & 80 & 58 & 3 & $65 \%$ & $29 \%$ & 10.6 months \\
\hline Hillmen et al' & $\mathrm{FCM}+\mathrm{R}$ & 23 & 65 & 2 & $70 \%$ & $42 \% *$ & NR \\
\hline
\end{tabular}

Note: $* \mathrm{CR}+\mathrm{CR}$ with incomplete marrow recovery.

Abbreviations: NR, not reported; F, fludarabine; C, cyclophosphamide; R, rituximab; L, lumiliximab; A, alemtuzumab; M, mitoxantrone; B, bendamustin; HDMP, high-dose methylprednisolone; R-C, rituximab, cladribine; R-CC, rituximab, cladribine, cyclophosphamide; OR, overall response; CR, complete response; PFS, progression free survival. 
Hillmen et al ${ }^{110}$ compared an FCM (fludarabine, cyclophosphamide, mitoxantrone) regimen with FCM + rituximab in previously treated CLL. The OR rates to FCM and FCM-R were $58 \%$ and $65 \%$, respectively. The toxicity of both regimens was similar and acceptable. Faderl et al reported the results of FCM-R regimen in previously untreated patients. ${ }^{111}$ In this study, OR was $96 \%$ and CR was $83 \%$. However, the efficiency and toxicity of this four-drug combination is similar to the standard R-FC immunochemotherapy used as the historical control. Bosch et al reported a Phase II clinical trial consisting of an initial treatment with R-FCM followed by rituximab maintenance. ${ }^{12}$ Patients achieving response after FCM-R immunochemotherapy received rituximab $375 \mathrm{mg} / \mathrm{m}^{2}$ every 3 months for 2 years. The OR rate was $93 \%$, including $82 \% \mathrm{CR}$.

In a Phase I/II study by Byrd et al, ${ }^{113}$ an $\mathrm{R}-\mathrm{FC}$ regimen combined with anti-CD23 mAb lumiliximab was tested in patients with refractory/relapsed CLL. The OR rate was $65 \%$, including $52 \% \mathrm{CR}$. The $\mathrm{CR}$ rate in this study compared favorably for R-FC and lumiliximab with the activity of R-FC alone in a similar patient population $(25 \% \mathrm{CR})$ previously reported by Wierda et al. ${ }^{105}$

Alemtuzumab has also been added to R-FC (CFAR) for the treatment of previously treated and untreated CLL patients. ${ }^{115}$ In relapsed or refractory patients the OR rate was $65 \%$, including 29\% CR. However, there was no significant improvement in PFS and OS in comparison with a similar historical group treated with R-FC in the same center. CFAR was also evaluated in younger untreated patients. ${ }^{115}$ However, response rates and survival of the majority of patients treated with CFAR are comparable with those of R-FC-treated patients.

Recent clinical observations reveal that rituximab can be also combined with other PNAs, DCF, or 2-CdA (Table 6). Lemanna et al $^{116}$ treated 32 refractory or relapsed patients with DCF, CY, and rituximab (PCR regimen) and found 24 responses (75\%) including eight CRs $(25 \%)$. The median duration of response was 25 months and the median time to treatment failure was 40 months. Kay et al ${ }^{117}$ presented the results of PCR in previously untreated patients. Responses occurred in 58 out of 65 patients (91\%) with 26 (41\%) CR.

A PCR regimen may be a good therapeutic option for older patients and those with modestly decreased renal function. ${ }^{118}$ Reynolds et al ${ }^{119}$ compared R-FC and PCR regimens in previously untreated or minimally treated CLL in a randomized study. The OR rate was higher in the R-FC group (59\%) than in the PCR arm (49\%), which demonstrated CR rates of $14 \%$ and $7 \%$, respectively. Efficacy and toxicity of combined therapy consisting of rituximab and 2-CdA ( $\mathrm{RC}$ protocol) or 2-CdA, CY, and rituximab ( $\mathrm{RCC}$ protocol) were also evaluated in patients with refractory or relapsed CLL. ${ }^{120}$ Among the 46 patients that entered the study, three patients (6.5\%) achieved CR and $31(67 \%)$ patients achieved PR.

Combinations of high-dose methyl prednisolone (HDMP) with rituximab were investigated in relapsed/refractory and previously untreated patients. ${ }^{121,122}$ In previously untreated patients, the OR rate was $96 \%$, CR rate $32 \%$, and the median PFS was 30.3 months. ${ }^{122}$ This treatment can be particularly useful for patients with limited myeloid reserve that might not tolerate other therapies. In one study, 14 refractory or relapsed patients were treated with three cycles of rituximab ( $375 \mathrm{mg} / \mathrm{m}^{2}$ weekly for 4 weeks) in combination with HDMP ( $1 \mathrm{gm} / \mathrm{m}^{2}$ daily for 5 days). The OR rate was $93 \%$ and the CR rate was $36 \%$. The median PFS was 15 months. HDMP and rituximab were well tolerated and had promising activity in this patient population.

Encouraging results were also obtained using rituximab in combination with bendamustine (RB). In a study performed by Fisher et al, 78 relapsed or refractory patients received $70 \mathrm{mg} / \mathrm{m}^{2}$ of bendamustine on days 1 and 2 , and $375 \mathrm{mg} / \mathrm{m}^{2}$ of rituximab on day 1 of the first cycle and $500 \mathrm{mg} / \mathrm{m}^{2}$ on day 1 of up to six subsequent 28 -day cycles. ${ }^{123}$ The OR rate was $59 \%$ and CR $9.0 \%$. After a median follow-up time of 24 months, the median event-free survival was 14.7 months. Subsequently, a multicenter Phase II trial (CLL2M) was performed to evaluate the efficacy and toxicity of $\mathrm{RB}$ in previously untreated CLL patients. ${ }^{124}$ The OR rate was $90.9 \%$ with $32.7 \%$ CR. After 18 months, $75.8 \%$ of the patients were still in remission and median PFS had not been reached. Alemtuzumab was also combined with rituximab, with significant responsiveness and acceptable toxicity. ${ }^{125-127}$

\section{Optimal use of rituximab}

In routine use, rituximab is usually administered intravenously as a single agent or as part of combination chemoimmunotherapy. ${ }^{128}$ Rituximab is almost exclusively administered slowly via the intravenous route. The standard dose of rituximab used for the treatment of patients with NHL is $375 \mathrm{mg} / \mathrm{m}^{2}$ administered as an intravenous infusion once weekly for 4 weeks. However, the results of a Phase I doseescalation study indicate that higher doses of rituximab are more effective and relatively well tolerated. ${ }^{129}$ In CLL, there is clear evidence of a dose-response relationship. In a study performed by O'Brien et al, ${ }^{94}$ the OR rate was found to be $22 \%$ for patients treated at 500 to $825 \mathrm{mg} / \mathrm{m}^{2}, 43 \%$ for those 
Table 6 Larger studies evaluating the efficacy of rituximab combined with other drugs than fludarabine in previously untreated and pretreated patients with CLL

\begin{tabular}{|c|c|c|c|c|c|c|c|}
\hline Study & Treatment & No of patients & Median age & $\begin{array}{l}\text { No of previous } \\
\text { treatments }\end{array}$ & OR & CR & Median PFS \\
\hline Kay et al ${ }^{117}$ & R-PC & 65 & 63 & 0 & $91 \%$ & $41 \%$ & 32.6 months \\
\hline Lamanna et al'16 & R-PC & 32 & 62 & 2 & $75 \%$ & $25 \%$ & 25 months \\
\hline Robak et al ${ }^{120}$ & $\mathrm{R}-\mathrm{C} / \mathrm{R}-\mathrm{CC}$ & 46 & 59 & 2 & $67 \%$ & $7 \%$ & 12 months \\
\hline Fischer et al ${ }^{124}$ & $\mathrm{R}-\mathrm{B}$ & 117 & 64 & 0 & $90.9 \%$ & $32.7 \%$ & Not reached \\
\hline Fischer et al ${ }^{123}$ & $R-B$ & 81 & 67 & 2 & $77 \%$ & $14 \%$ & NR \\
\hline Castro et al $\left.\right|^{122}$ & R-HDMP & 28 & 65 & 0 & $96 \%$ & $32 \%$ & 30.3 months \\
\hline Bowen et al ${ }^{121}$ & R-HDMP & 37 & 67 & 2 & $78 \%$ & $22 \%$ & 12 months \\
\hline Zent $^{126}$ & $\mathrm{R}+\mathrm{A}$ & 30 & 61 & 0 & $90 \%$ & $37 \%$ & I 4.4 months \\
\hline Faderl et al ${ }^{127}$ & $\mathrm{R}+\mathrm{A}$ & 40 & 59 & 3 & $53 \%$ & $18 \%$ & 6 months \\
\hline
\end{tabular}

Abbreviations: NR, not reported; F, fludarabine; C, cyclophosphamide; R, rituximab; L, lumiliximab; A, alemtuzumab; M, mitoxantrone; B, bendamustin; HDMP, high-dose methylprednisolone; R-C, rituximab + cladribine; R-CC, rituximab + cladribine + cyclophosphamide; OR, overall response; CR, complete response; PFS, progression free survival.

treated at 1000 to $1500 \mathrm{mg} / \mathrm{m}^{2}$, and $75 \%$ for those treated at the highest dose of $2250 \mathrm{mg} / \mathrm{m}^{2}(P=0.007)$.

Data relating to the safety, efficacy, and PK of other routes of administration are incomplete. Novel routes of administration include subcutaneous, intrathecal, intraventricular, intrapleural, intralesional, intradermal, and even intravitreal use. Fractionated subcutaneous dosing schedules that limit exhaustion of effector mechanisms may be more effective than current intravenous bolus schedules of rituximab at a dose of $375 \mathrm{mg} / \mathrm{m}^{2}{ }^{130}$ A pilot trial suggests that low-dose rituximab at $20 \mathrm{mg} / \mathrm{m}^{2}$ intravenously thrice weekly promotes clearance of leukemic cells without inducing loss of targeted CD20. ${ }^{131}$ Lower doses of this antibody (20 mg) administered subcutaneously thrice weekly for up to 12 weeks was well tolerated with minimal injection site reactions. ${ }^{130}$ Subcutaneous rituximab largely preserved CD20 expression on leukemic cells. Subcutaneous administration could be more convenient for the patients than intravenous treatment. In fact, higher subcutaneous doses of rituximab could be more effective than lower doses. However, the safety of this approach should be confirmed in a larger cohort of patients and possible development of human anti-chimeric antibodies (HACA) would have to be studied. At present, subcutaneous rituximab administration should not be repeated outside of clinical trials. Intraventricular administration of rituximab has been evaluated in Phase I trials and was effective in some cases with central nervous system (CNS) lymphoma. ${ }^{132,133}$

Intrapleural and intraperitoneal administration of rituximab for the treatment of recurrent malignant pleural effusions or abdominal ascites unresponsive to systemic therapy have been reported in individual cases with NHL. ${ }^{134-137}$ The intracavity administration of rituximab seems to be effective in some cases with no significant side effects.

\section{Conclusions and place in therapy}

Rituximab was the first mAb approved in 1997 by the FDA for the treatment of FL. Although the introduction of rituximab has not led to the development of curative treatments, it has markedly prolonged the PFS and OS of patients with FL. Currently, this drug is commonly combined with firstline chemotherapy for FL, and retreatment with rituximab is typically reserved until first relapse. In addition, the results of the PRIMA study showed that rituximab maintenance doubled the PFS of patients with FL compared to those who stopped treatment. The PRIMA study is particularly important because rituximab maintenance therapy was added as a further stage after induction with immunochemotherapy regimens in previously untreated patients, and this combination has recently become a treatment of choice for patients with FL. The results from this trial should conclusively establish the favorable role of rituximab in maintenance therapy in FL. Based on the currently available evidence, rituximab should be offered as maintenance therapy to all appropriate patients with FL rather than waiting until relapse. In January 2011, the FDA approved rituximab for maintenance therapy for patients with previously untreated FL who achieve a response to rituximab in combination with chemotherapy.

Randomized Phase III trials have demonstrated the superiority of R-CHOP over CHOP chemotherapy alone in patients with DLBCL. In February 2006, the FDA granted approval to rituximab for use in combination with $\mathrm{CHOP}$ or other anthracycline-based chemotherapy regimens in the first-line treatment of patients with DLBCL. Despite the significant progress in the first-line treatment of DLBCL, up to $50 \%$ of patients relapse after chemoimmunotherapy with R-CHOP, especially if they belong to the high-risk population. In younger patients with relapsed or refractory DLBCL, salvage therapy followed by high-dose therapy with 
ASCT is currently the treatment of choice. The optimal salvage regimen should be defined on the basis of the ongoing CORAL study (Collaborative trial in Relapsed Aggressive Lymphoma), randomized relapsed patients between R-ICE (rituximab, ifosfamide, carboplatin, etoposide), and R-DHAP (rituximab, dexamethasone, cytarabinoside, cisplatin) salvage therapy prior to ASCT.

Rituximab alone has limited activity in MCL. However, this agent is currently widely used in MCL in combination with chemotherapy, although benefits are not as impressive as in other lymphoma entities, and other therapeutic strategies are needed in this disease.

Rituximab as a single agent also demonstrates moderate clinical activity in patients with CLL. However, when administered in combination with chemotherapy, rituximab can improve the survival of patients relative to those treated with chemotherapy alone. In 2009, the European Commission approved rituximab in combination with chemotherapy for use in patients with previously untreated and previously treated CLL. In February 2010, the FDA granted approval to rituximab, in combination with fludarabine and cyclophosphamide, for the treatment of both previously untreated and previously treated patients with CLL. ${ }^{138}$ These approvals were based on two large Phase III randomized trials that demonstrated the superiority of chemoimmunotherapy with rituximab compared with chemotherapy alone in previously untreated and refractory/ relapsed patients with CLL.

Over the last few years, new generations of antiCD20 mAbs have been developed for potential benefits over the classical, first-generation mAb rituximab. ${ }^{139}$ Some of them are potentially useful in the treatment of lymphoid malignancies. Compared with rituximab, new mAbs have enhanced antitumor activity resulting from increased complement-dependent cytotoxicity (CDC) and/or antibody-dependent cellular cytotoxicity (ADCC), and increased Fc binding affinity for the low-affinity variants of the FcyRIIIa receptor on immune effector cells. In particular, ofatumumab specifically recognizes an epitope encompassing both the small and large extracellular loops of CD20 molecule, and is more effective than rituximab at CDC induction and killing target cells. ${ }^{140}$ Obinutuzumab (GA-101) was designed for enhanced ADCC and superior direct cell-killing properties, in comparison with currently available type I antibodies. ${ }^{141}$ However, an advantage of these new anti-CD20 mAbs over rituximab needs to be further documented in well-designed, randomized trials. Therefore it can be concluded that, until the results from such trials are available, rituximab is generally accepted as a standard component of therapies for B-cell lymphoid malignancies. ${ }^{142,143}$

In B-cell lymphoid malignancies, rituximab has been combined successfully in chemoimmunotherapy regimens with several standard chemotherapy combinations. Thus, although traditional strategies can still have a role in standard therapies, such approaches must now be placed in perspective with options that have the potential to achieve durable disease control or even cure. It is the hope that potentially curative treatment options may be forthcoming for these patients when rituximab, or newer anti-CD20 monoclonal antibodies, will be combined with emergent targeted drugs such as flavopiridol, lenalidomide, and orally bioavailable tyrosine kinase inhibitors, with potential activity in lymphoid malignancies. Immunotherapy with rituximab and these agents promises increased lymphoma specificity, reduced toxicity, and synergistic efficacy based on their different modes of action.

\section{Acknowledgments}

This work was supported in part by the grant from the Medical University of Łódź (No 503-1093-1) and by the Foundation for the Development of Diagnostics and Therapy, Warsaw, Poland.

\section{Disclosure}

TR and PS received research grants and travel grants from Hoffmann-La Roche. PR has no disclosures to make.

\section{References}

1. Jaffe ES. The 2008 WHO classification of lymphomas: implications for clinical practice and translational research. Hematology Am Soc Hematol Educ Program. 2009:523-531.

2. Alexander DD. The non-Hodgkin lymphomas: a review of the epidemiologic literature. Int J Cancer. 2007;120 Suppl 12:1-39.

3. American Cancer Society. Cancer facts and figures 2011. Available from: http://www.cancer.org/acs/groups/cid/documents/webcontent/003067pdf.pdf. Accessed November 30, 2011.

4. Swerdlow SH, Campo E, Harris NL, et al. World Health Organization Classification of Tumors of Haematopoietic and Lymphoid Tissues. Lyon, France: IARC Press; 2008.

5. Tsang RW, Gospodarowicz MK. Low-grade non-hodgkin lymphomas. Semin Radiat Oncol. 2007;17(3):198-205.

6. Hunt KE, Reichard KK. Diffuse large B-cell lymphoma. Arch Pathol Lab Med. 2008;132:118-1124.

7. Gribben JG. How I treat indolent lymphoma. Blood. 2007;109(11): $4617-4626$.

8. Redaelli A, Laskin BL, Stephens JM, Botteman MF, Pashos CL. The clinical and epidemiological burden of chronic lymphocytic leukaemia. Eur J Cancer Care (Engl). 2004;13(3):279-287.

9. CLL Trialists' Collaborative Group. Chemotherapeutic options in chronic lymphocytic leukemia: a meta-analysis of the randomized trials. $J$ Natl Cancer Inst. 1999;91(10):861-868. 
10. Robak T, Kasznicki M. Alkylating agents and nucleoside analogues in the treatment of B cell chronic lymphocytic leukemia. Leukemia. 2002; 16(6):1015-1027.

11. Rai KR, Peterson BL, Appelbaum FR, et al. Fludarabine compared with chlorambucil as primary therapy for chronic lymphocytic leukemia. N Engl J Med. 2000;343(24):1750-1757.

12. Robak T, Blonski JZ, Kasznicki M, et al. Cladribine with prednisone versus chlorambucil with prednisone as first-line therapy in chronic lymphocytic leukemia: report of a prospective, randomized, multicenter trial. Blood. 2000;96(8):2723-2729.

13. Eichhorst BF, Busch R, Hopfinger G, et al. Fludarabine pluscyclophosphamide versus fludarabine alone in first-line therapy of younger patients with chronic lymphocytic leukemia. Blood. 2006;107(3):885-891.

14. Robak T, Jamroziak K, Gora-Tybor J, et al. Comparison of cladribine plus cyclophosphamide with fludarabine plus cyclophosphamide as first-line therapy for chronic lymphocytic leukemia: a phase III randomized study by the Polish Adult Leukemia Group (PALG-CLL3 Study). J Clin Oncol. 2010;28(11):1861-1869.

15. Hallek M, Fischer K, Fingerle-Rowson G, et al. Addition of rituximab to fludarabine and cyclophosphamide in patients with chronic lymphocytic leukaemia: a randomised, open-label, phase 3 trial. Lancet. 2010; 376(9747):1164-1174.

16. Robak T, Dmoszynska A, Solal-Celigny A, et al. Rituximab plus fludarabine and cyclophosphamide prolongs progression-free survival compared with fludarabine and cyclophosphamide alone in previouslytreated chronic lymphocytic leukemia. J Clin Oncol. 2010;28(10): 1756-1765.

17. Keating GM. Rituximab: a review of its use in chronic lymphocytic leukaemia, low-grade or follicular lymphoma and diffuse large B-cell lymphoma. Drugs. 2010;70(11):1445-1476.

18. Reff ME, Carner K, Chambers KS, et al. Depletion of B cells in vivo by a chimeric mouse human monoclonal antibody to CD20. Blood. 1994; 83(2):435-445.

19. Cragg MS, Walshe CA, Ivanov AO, Glennie MJ. The biology of CD20 and its potential as a target for mAb therapy. Curr Dir Autoimmun. 2005;8:140-174.

20. Beers SA, Chan CH, French RR, Cragg MS, Glennie MJ. CD20 as a target for therapeutic type I and II monoclonal antibodies. Semin Hematol. 2010;47(2):107-114.

21. Li H, Ayer LM, Lytton J, Deans JP. Store-operated cation entry mediated by CD20 in membrane rafts. J Biol Chem. 2003;278(43): 42427-42434.

22. Giles FJ, Vose JM, Do KA, et al. Circulating CD20 and CD52 in patients with non-Hodgkin's lymphoma or Hodgkin's disease. Br J Haematol. 2003;123(5):850-857.

23. Maloney DG. Mechanism of action of rituximab. Anticancer Drugs. 2001;12 Suppl 2:S1-S4.

24. Zhou X, Hu W, Qin X. The role of complement in the mechanism of action of rituximab for B-cell lymphoma: implications for therapy. Oncologist. 2008;13(9):954-966.

25. Manches O, Lui G, Chapero L, et al. In vitro mechanism of action of rituximab on primary non-Hodgkin lymphomas. Blood. 2003;101(3): 949-954.

26. Shan D, Ledbetter JA, Press OW. Apoptosis of malignant human B cells by ligation of CD20 with monoclonal antibodies. Blood. 1998; 91(5):1644-1652.

27. Golay J, Zaffaroni L, Vaccari T, et al. Biologic response of B lymphoma cells to anti-CD20 monoclonal antibody rituximab in vitro: CD55 and CD59 regulate complement mediated cell lysis. Blood. 2000;95(12): 3900-3908.

28. Cragg MS, Morgan SM, Chan HT, et al. Complement-mediated lysis by anti-CD20 mAb correlates with segregation into lipid rafts. Blood. 2003;101(3):1045-1052.

29. Byrd JC, Kitada S, Flinn IW, et al. The mechanism of tumor cell clearance by rituximab in vivo in patients with B-cell chronic lymphocytic leukemia: evidence of caspase activation and apoptosis induction. Blood. 2002;99(3):1038-1043.
30. Suzuki E, Umezawa K, Bonavida B. Rituximab inhibits the constitutively activated PI3K-Akt pathway in B-NHL cell lines: Involvement in chemosensitization to drug-induced apoptosis. Oncogene. 2007; 26(42):6184-6193.

31. Chow KU, Sommerlad WD, Boehrer S, et al. Anti-CD20 antibody (IDEC-C238, rituximab) enhances efficacy of cytotoxic drugs on neoplastic lymphocytes in vitro: role of cytokines, complement, and caspases. Haematologica. 2002;87(1):33-43.

32. Rodriguez J, Gutierrez A. Pharmacokinetic properties of rituximab. Rev Recent Clin Trials. 2008;3(1):22-30.

33. Berinstein NL, Grillo-Lopez AJ, White CA, et al. Association of serum Rituximab (IDEC-C2B8) concentration and anti-tumor response in the treatment of recurrent low-grade or follicular non-Hodgkin's lymphoma. Ann Oncol. 1998;9(9):995-1001.

34. Cartron G, Blasco H, Paintaud G, et al. Pharmacokinetics of rituximab and its clinical use: thought for the best use? Crit Rev Oncol Hematol. 2007;62(1):43-52.

35. Maloney DG, Grillo-Lopez AJ, Bodkin DJ, et al. IDEC-C2B8: results of a phase I multiple-dose trial in patients with relapsed non-Hodgkin's lymphoma. J Clin Oncol. 1997;15(10):3266-3274.

36. Maloney D, Grillo-Lopez AJ, Link BK, et al. IDEC-C2B8 (Rituximab) anti-CD20 monoclonal antibody therapy in patients with relapsed lowgrade non-Hodgkin's lymphoma. Blood. 1997;90(6):2188-2195.

37. Piro LD, White CA, Grillo-Lopez AJ, et al. Extended Rituximab (antiCD20 monoclonal antibody) therapy for relapsed or refractory lowgrade or follicular non-Hodgkin's lymphoma. Ann Oncol. 1999;10(6): 655-661.

38. Tran L, Baars JW, Aarden L, Beijnen JH, Huitema AD. Pharmacokinetics of rituximab in patients with $\mathrm{CD} 20$ positive B-cell malignancies. Hum Antibodies. 2010;19(1):7-13.

39. Regazzi MB, Iacona I, Avanzini MA, et al. Pharmacokinetic behavior of rituximab: a study of different schedules of administration for heterogeneous clinical settings. Ther Drug Monit. 2005;27(6):785-792.

40. Mangel J, Buckstein R, Imrie K, et al. Pharmacokinetic study of patients with follicular or mantle cell lymphoma treated with rituximab as 'in vivo purge' and consolidative immunotherapy following autologous stem cell transplantation. Ann Oncol. 2003;14(5):758-765.

41. Ternant D, Paintaud G. Pharmacokinetics and concentration-effect relationships of therapeutic monoclonal antibodies and fusion proteins. Expert Opin Biol Ther. 2005;5 Suppl 1:S37-S47.

42. Ternant D, Cartron G, Hénin E, Tod M, Girard P, Paintaud G. Model-based design of rituximab dosage optimisation in follicular non-Hodgkin's lymphoma. Br J Clin Pharmacol. 2011. [Epub ahead of print.]

43. Ganjoo KN, An CS, Robertson MJ, et al. Rituximab, bevacizumab and CHOP (RA-CHOP) in untreated diffuse large B-cell lymphoma: safety, biomarker and pharmacokinetic analysis. Leuk Lymphoma. 2006; 47(6):998-1005.

44. Blasco H, Chatelut E, de Bretagne IB, et al. Pharmacokinetics of rituximab associated with $\mathrm{CHOP}$ chemotherapy in B-cell non-Hodgkin lymphoma. Fundam Clin Pharmacol. 2009;23(5):601-608.

45. Scheidhauer K, Wolf I, Baumgartl HJ, et al. Biodistribution and kinetics of (131)I-labelled anti-CD20 MAB IDEC-C2B8 (rituximab) in relapsed non-Hodgkin's lymphoma. Eur J Nucl Med Mol Imaging. 2002;29(10):1276-1282.

46. Plosker GL, Figgitt DP. Rituximab: a review of its use in non-Hodgkin's lymphoma and chronic lymphocytic leukaemia. Drugs. 2003;63(8): 803-843.

47. Maeda T, Yamada Y, Tawara M, et al. Successful treatment with a chimeric anti-CD20 monoclonal antibody (IDEC-C2B8, rituximab) for a patient with relapsed mantle cell lymphoma who developed a human anti-chimeric antibody. Int J Hematol. 2001;74(1):70-75.

48. Casulo C, Maragulia J, Zelenetz AD. Hypogammaglobulinemia in pts receiving rituximab immunotherapy and the impact of rituximab maintenance. J Clin Oncol. 2010;28:S15.

49. Villadolid J, Laplant KD, Markham MJ, Nelson DR, George TJ Jr. Hepatitis B reactivation and rituximab in the oncology practice. Oncologist. 2010;15(10):1113-1121. 
50. Koo YX, Tay M, Teh YE, et al. Risk of hepatitis B virus (HBV) reactivation in hepatitis $\mathrm{B}$ surface antigen negative/hepatitis $\mathrm{B}$ core antibody positive patients receiving rituximab-containing combination chemotherapy without routine antiviral prophylaxis. Ann Hematol. 2011;90(10):1219-1223.

51. Niitsu N, Hagiwara Y, Tanae K, Kohri M, Takahashi N. Prospective analysis of hepatitis B virus reactivation in patients with diffuse large B-cell lymphoma after rituximab combination chemotherapy. $J$ Clin Oncol. 2010;28(34):5097-5100.

52. Precupanu CM, Girodet J, Mariani P, et al. Pseudo-bowel obstruction due to varicella zoster virus infection after autologous stem cell transplantation. Am J Hematol. 2009;84(2):127-128.

53. Song KW, Mollee P, Patterson B, Brien W, Crump M. Pure red cell aplasia due to parvovirus following treatment with $\mathrm{CHOP}$ and rituximab for B-cell lymphoma. Br J Haematol. 2002;119(1):125-127.

54. Mawhorter SD, Sierk A, Staugaitis SM, et al. Fatal West Nile Virus infection after rituximab/fludarabine - induced remission for nonHodgkin's lymphoma. Clin Lymphoma Myeloma. 2005;6(3):248-250.

55. Tuccori M, Focosi D, Blandizzi C, et al. Inclusion of rituximab in treatment protocols for non-Hodgkin's lymphomas and risk for progressive multifocal leukoencephalopathy. Oncologist. 2010;15(11): 1214-1219.

56. Ram R, Ben-Bassat I, Shpilberg O, Polliack A, Raanani P. The late adverse events of rituximab therapy - rare but there! Leuk Lymphoma. 2009;50(7):1083-1095.

57. Lanini S, Molloy AC, Fine PE, Prentice AG, Ippolito G, Kibbler CC. Risk of infection in patients with lymphoma receiving rituximab: systematic review and meta-analysis. BMC Med. 2011;9:36.

58. Dreyling M, Trümper L, von Schilling $C$, et al. Results of a national consensus workshop: therapeutic algorithm in patients with follicular lymphoma - role of radioimmunotherapy. Ann Hematol. 2007; 86(2):81-87.

59. Lunning M, Armitage JO. The curability of follicular lymphoma. Transfus Apher Sci. 2007;37(1):31-35.

60. Dreyling M; ESMO Guidelines Working Group. Newly diagnosed and relapsed follicular lymphoma: ESMO Clinical Practice Guidelines for diagnosis, treatment and follow-up. Ann Oncol. 2010;21 Suppl 5: v181-v183.

61. Marcus R, Imrie K, Belch A, et al. CVP chemotherapy plus rituximab compared with CVP as first-line treatment for advanced follicular lymphoma. Blood. 2005;105(4):1417-1423.

62. Hochster H, Weller E, Gascoyne RD, et al. Maintenance rituximab after cyclophosphamide, vincristine, and prednisone prolongs progressionfree survival in advanced indolent lymphoma: results of the randomized phase III ECOG1496 Study. J Clin Oncol. 2009;27(10):1607-1614.

63. van Oers MH, Van Glabbeke M, Giurgea L, et al. Rituximab maintenance treatment of relapsed/resistant follicular non-Hodgkin's lymphoma: long-term outcome of the EORTC 20981 phase III randomized intergroup study. J Clin Oncol. 2010;28(17):2853-2858.

64. Forstpointner R, Unterhalt M, Dreyling M, et al; German Low Grade Lymphoma Study Group (GLSG). Maintenance therapy with rituximab leads to a significant prolongation of response duration after salvage therapy with a combination of rituximab, fludarabine, cyclophosphamide, and mitoxantrone (R-FCM) in patients with recurring and refractory follicular and mantle cell lymphomas: Results of a prospective randomized study of the German Low Grade Lymphoma Study Group (GLSG). Blood. 2006;108(13):4003-4008.

65. Ghielmini M, Schmitz SF, Cogliatti SB, et al. Prolonged treatment with rituximab in patients with follicular lymphoma significantly increases event-free survival and response duration compared with the standard weekly $\times 4$ schedule. Blood. 2004;103(12):4416-4423.

66. Hainsworth JD, Litchy S, Shaffer DW, Lackey VL, Grimaldi M, Greco FA. Maximizing therapeutic benefit of rituximab: maintenance therapy versus re-treatment at progression in patients with indolent non-Hodgkin's lymphoma - a randomized phase II trial of the Minnie Pearl Cancer Research Network. J Clin Oncol. 2005; 23(6):1088-1095
67. Vidal L, Gafter-Gvili A, Leibovici L, et al. Rituximab maintenance for the treatment of patients with follicular lymphoma: systematic review and meta-analysis of randomized trials. J Natl Cancer Inst. 2009; 101(4):248-255.

68. Salles G, Seymour JF, Offner F, et al. Rituximab maintenance for 2 years in patients with high tumour burden follicular lymphoma responding to rituximab plus chemotherapy (PRIMA): a phase 3, randomised controlled trial. Lancet. 2011;377(9759):42-51.

69. Coiffier B, Haioun C, Ketterer N, et al. Rituximab (anti-CD20 monoclonal antibody) for the treatment of patients with relapsing or refractory aggressive lymphoma: a multicenter phase II study. Blood. 1998; 92(6): 1927-1932.

70. Coiffier B, Lepage E, Briere J, et al. CHOP chemotherapy plus rituximab compared with CHOP alone in elderly patients with diffuse large-B-cell lymphoma. $N$ Engl J Med. 2002;346(4):235-242.

71. Habermann TM, Weller EA, Morrison VA, et al. Rituximab-CHOP versus $\mathrm{CHOP}$ alone or with maintenance rituximab in older patients with diffuse large B-cell lymphoma. J Clin Oncol. 2006;24(19):3121-3127.

72. Pfreundschuh M, Schubert J, Ziepert M, et al; German High-Grade NonHodgkin Lymphoma Study Group (DSHNHL). Six versus eight cycles of bi-weekly CHOP-14 with or without rituximab in elderly patients with aggressive CD20+ B-cell lymphomas: a randomised controlled trial (RICOVER-60). Lancet Oncol. 2008;9(2):105-116.

73. Pfreundschuh M, Trumper L, Osterborg A, et al; MabThera International Trial Group. CHOP-like chemotherapy plus rituximab versus CHOPlike chemotherapy alone in young patients with good-prognosis diffuse large-B-cell lymphoma: a randomised controlled trial by the MabThera International Trial (MInT) Group. Lancet Oncol. 2006;7(5):379-391.

74. Vose JM, Link BK, Grossbard ML, et al. Phase II study of rituximab in combination with chop chemotherapy in patients with previously untreated, aggressive non-Hodgkin's lymphoma. J Clin Oncol. 2001; 19(2):389-397.

75. Pfreundschuh M, Kuhnt E, Trümper L, et al; MabThera International Trial (MInT) Group. CHOP-like chemotherapy with or without rituximab in young patients with good-prognosis diffuse large-B-cell lymphoma: 6-year results of an open-label randomised study of the MabThera International Trial (MInT) Group. Lancet Oncol. 2011; 12(11):1013-1022.

76. Philip T, Guglielmi C, Hagenbeek A, et al. Autologous bone marrow transplantation as compared with salvage chemotherapy in relapses of chemotherapy-sensitive non-Hodgkin's lymphoma. $N$ Engl J Med. 1995;333(23):1540-1545.

77. Kewalramani T, Zelenetz AD, Nimer SD, et al. Rituximab and ICE as second-line therapy before autologous stem cell transplantation for relapsed or primary refractory diffuse large B-cell lymphoma. Blood. 2004;103(10):3684-3688.

78. Sieniawski M, Staak O, Glossmann JP, et al. Rituximab added to an intensified salvage chemotherapy program followed by autologous stem cell transplantation improved the outcome in relapsed and refractory aggressive non-Hodgkin lymphoma. Ann Hematol. 2007;86(2): $107-115$.

79. Hess G, Flohr T, Kolbe K, et al. Effect of rituximab on the long-term outcome after high-dose therapy for relapsed B-cell non-Hodgkin's lymphoma. Ann Hematol. 2006;85(11):769-779.

80. Gisselbrecht C, Schmitz N, Mounier N, et al. R-ICE versus R-DHAP in relapsed patients with CD20 diffuse large B-Cell lymphoma (DLBCL) followed by stem cell transplantation and maintenance treatment with rituximab or not: First interim analysis on 200 patients. CORAL Study. Blood. 2007;110(11):517.

81. Tarella C, Zanni M, Magni M, et al. Rituximab improves the efficacy of high-dose chemotherapy with autograft for high-risk follicular and diffuse large B-cell lymphoma: a multicenter Gruppo Italiano Terapie Innnovative nei linfomi survey. J Clin Oncol. 2008;26(19):3166-3175.

82. Ghielmini M, Schmitz SF, Cogliatti S, et al. Effect of single-agent rituximab given at the standard schedule or as prolonged treatment in patients with mantle cell lymphoma: a study of the Swiss Group for Clinical Cancer Research (SAKK). J Clin Oncol. 2005;23(4):705-711. 
83. Lenz G, Dreyling M, Hoster E, et al. Immunochemotherapy with rituximab and cyclophosphamide, doxorubicin, vincristine, and prednisone significantly improves response and time to treatment failure, but not long-term outcome in patients with previously untreated mantle cell lymphoma: results of a prospective randomized trial of the German Low Grade Lymphoma Study Group (GLSG). J Clin Oncol. 2005; 23(9):1984-1992.

84. Romaguera JE, Fayad L, Rodriguez MA, et al. High Rate of durable remissions after treatment of newly diagnosed aggressive mantle-cell lymphoma with rituximab plus hyper-CVAD alternating with rituximab plus high-dose methotrexate and cytarabine. J Clin Oncol. 2005; 23(28):7013-7023.

85. Schulz H, Bohlius JF, Trelle S, et al. Immunochemotherapy with rituximab and overall survival in patients with indolent or mantle cell lymphoma: a systematic review and metaanalysis. J Natl Cancer Inst. 2007;99(9):706-714.

86. Herold M, Pasold R, Srock S, et al. Results of a prospective randomised open label phase III study comparing rituximab plus mitoxantrone, chlorambucile, prednisolone chemotherapy (R-MCP) versus MCP alone in untreated advanced indolent non-Hodgkin's lymphoma (NHL) and mantle-cell lymphoma (MCL). (abstract). Blood. 2004;104 Suppl 1: S169:584.

87. Herrmann A, Hoster E, Zwingers T, et al. Improvement of overall survival in advanced mantle cell lymphoma. J Clin Oncol. 2009; 27(4):511-518.

88. Griffiths R, Mikhael J, Gleeson M, et al. Addition of rituximab to chemotherapy alone as first-line therapy improves overall survival in elderly patients with mantle cell lymphoma. Blood. 2011;118(18): 4808-4816.

89. Forstpointer R, Dreyling M, Repp R, et al. The addition of rituximab to a combination of fludarabine, cyclophosphamide, mitoxantrone (FCM) significantly increases the response rate and prolongs survival as compared with FCM alone in patients with relapsed and refractory follicular and mantle cell lymphomas: results of a prospective randomized study of the German Low-Grade Lymphoma Study Group. Blood. 2004;104(10):3064-3071.

90. Hoerr AL, Gao F, Hidalgo JT, et al. Effects of pretransplantation treatment with rituximab on outcomes of autologous stem-cell transplantation for non-Hodgkin's lymphoma. J Clin Oncol. 2004; 22(22):4561-4566.

91. Dreger P, Rieger M, Seyfarth B, et al. Rituximab-augmented myeloablation for first-line autologous stem cell transplantation for mantle cell lymphoma: effects on molecular response and clinical outcome. Haematologica. 2007;92(1):42-49.

92. Forstpointner R, Unterhalt M, Dreyling M, e al; German Low Grade Lymphoma Study Group (GLSG). Maintenance therapy with rituximab leads to a significant prolongation of response duration after salvage therapy with a combination of rituximab, fludarabine, cyclophosphamide, and mitoxantrone (R-FCM) in patients with recurring and refractory follicular and mantle cell lymphomas: Results of a prospective randomized study of the German Low Grade Lymphoma Study Group (GLSG). Blood. 2006;108(13):4003-4008.

93. Itala M, Geisler CH, Kimby E, et al. Standard dose anti-CD20 antibody rituximab has efficacy in chronic lymphocytic leukaemia: results from a Nordic multicentre study. Eur J Haematol. 2002;69(3):129-134.

94. O’Brien SM, Kantarjian H, Thomas DA, et al. Rituximab doseescalation trial in chronic lymphocytic leukemia. J Clin Oncol. 2001; 19(8):2165-2170.

95. Byrd JC, Murphy T, Howard RS, et al. Rituximab using a thrice weekly dosing schedule in B-cell chronic lymphocytic leukemia and small lymphocytic lymphoma demonstrates clinical activity and acceptable toxicity. J Clin Oncol. 2001;19(8):2153-2164.

96. Hainsworth JD, Litchy S, Barton JH, et al; Minnie Pearl Cancer Research Network. Single-agent rituximab as first-line and maintenance treatment for patients with chronic lymphocytic leukemia or small lymphocytic lymphoma: a phase II trial of the Minnie Pearl Cancer Research Network. J Clin Oncol. 2003;21(9):1746-1751.
97. Ferrajoli A, Keating MJ, O’Brien S, Cortes J, Thomas DA. Experience with rituximab immunotherapy as an early intervention in patients with Rai stage 0 to II chronic lymphocytic leukemia. Cancer. 2011; 117(14):3182-3186.

98. Byrd JC, Peterson BL, Morrison VA, et al. Randomized phase 2 study of fludarabine with concurrent vs sequential treatment with rituximab in symptomatic, untreated patients with B-cell chronic lymphocytic leukemia results from Cancer and Leukemia Group B 9712 (CALGB 9712). Blood. 2003;101(1):6-14.

99. Del Poeta G, DelPrincipe MI, Consalvo MA, et al. The addition of rituximab to fludarabine improves clinical outcome in untreated patients with ZAP-70-negative chronic lymphocytic leukemia. Cancer. 2005;104(12):2743-2752.

100. Schulz H, Klein SK, Rehwald U, et al. Phase 2 study of a combined immunochemotherapy using rituximab and fludarabine in patients with chronic lymphocytic leukemia. Blood. 2002;100(9): 3115-3120.

101. Byrd J, Rai K, Peterson BL, et al. Addition of rituximab to fludarabine may prolong progression-free survival and overall survival in patients with previously untreated chronic lymphocytic leukemia: an updated retrospective analysis of CALGB 9712 and CALGB 9011. Blood. 2005;105(1):49-53.

102. Woyach JA, Ruppert AS, Heerema NA, et al. Chemoimmunotherapy with fludarabine and rituximab produces extended overall survival and progression-free survival in chronic lymphocytic leukemia: long-term follow-up of CALGB study 9712. J Clin Oncol. 2011; 29(10):1349-1355.

103. Gerrie AS, Toze CL, Ramadan KM, et al. Oral fludarabine and rituximab as initial therapy for chronic lymphocytic leukemia or small lymphocytic lymphoma: population-based experience matches clinical trials. Leuk Lymphoma. 2011. [Epub ahead of print.]

104. Robak T, Lech-Maranda E, Robak P. Rituximab plus fludarabine and cyclophosphamide or other agents in chronic lymphocytic leukemia. Expert Rev Anticancer Ther. 2010;10(10):1529-1543.

105. Wierda W, O'Brien S, Wen S, et al. Chemoimmunotherapy with fludarabine, cyclophosphamide, and rituximab for relapsed and refractory chronic lymphocytic leukemia. J Clin Oncol. 2005;23(18): 4070-4078.

106. Keating MJ, O’Brien S, Albitar M, et al. Early results of a chemoimmunotherapy regimen of fludarabine, cyclophosphamide, and rituximab as initial therapy for chronic lymphocytic leukemia. J Clin Oncol. 2005;23(18):4079-4088

107. Tsimberidou AM, Tam C, Abruzzo LV, et al. Chemoimmunotherapy may overcome the adverse prognostic significance of $11 \mathrm{q}$ deletion in previously untreated patients with chronic lymphocytic leukemia. Cancer. 2009;115(2):373-380.

108. Foon KA, Boyiadzis M, Land SR, et al. Chemoimmunotherapy with low-dose fludarabine and cyclophosphamide and high dose rituximab in previously untreated patients with chronic lymphocytic leukemia. J Clin Oncol. 2009;27(4):498-503.

109. Robak T. Improving FCR immunochemotherapy in CLL. Blood. 2010; 115(3):437-438.

110. Hillmen P, Cohen DR, Cocks K, et al. A randomized phase II trial of fludarabine, cyclophosphamide and mitoxantrone (FCM) with or without rituximab in previously treated chronic lymphocytic leukaemia. Br J Haematol. 2011;152(5):570-578.

111. Faderl S, Wierda W, O’Brien S, et al. Fludarabine, cyclophosphamide, mitoxantrone plus rituximab (FCM-R) in frontline CLL $<70$ Years. Leuk Res. 2010;34(3):284-288.

112. Bosch F, Abrisqueta P, Villamor N, et al. Rituximab, fludarabine, cyclophosphamide, and mitoxantrone: a new, highly active chemoimmunotherapy regimen for chronic lymphocytic leukemia. J Clin Oncol. 2009;27(27):4578-4584.

113. Byrd JC, Kipps TJ, Flinn IW, et al. Phase $1 / 2$ study of lumiliximab combined with fludarabine, cyclophosphamide, and rituximab in patients with relapsed or refractory chronic lymphocytic leukemia. Blood. 2010;115(3):489-495. 
114. Badoux XC, Keating MJ, Wang X, et al. Fludarabine, cyclophosphamide, and rituximab chemoimmunotherapy is highly effective treatment for relapsed patients with CLL. Blood. 2011; 117(11):3016-3024.

115. Parikh SA, Keating MJ, O’Brien S, et al. Frontline chemoimmunotherapy with fludarabine, cyclophosphamide, alemtuzumab, and rituximab for high-risk chronic lymphocytic leukemia. Blood. 2011;118(8): 2062-2068.

116. Lamanna N, Kalaycio M, Maslak P, et al. Pentostatin, cyclophosphamide, and rituximab is an active, well-tolerated regimen for patients with previously treated chronic lymphocytic leukemia. J Clin Oncol. 2006;24(10):1575-1581.

117. Kay NE, Geyer SM, Call TG, et al. Combination chemoimmunotherapy with pentostatin, cyclophosphamide, and rituximab shows significant clinical activity with low accompanying toxicity in previously untreated B chronic lymphocytic leukemia. Blood. 2007;109(2):405-411.

118. Shanafelt TD, Lin T, Geyer SM, et al. Pentostatin, cyclophosphamide, and rituximab regimen in older patients with chronic lymphocytic leukemia. Cancer. 2007;109(11):2291-2298.

119. Reynolds C, Di Bella N, Lyons RM, et al. A Phase III trial of fludarabine, cyclophosphamide, and rituximab vs. pentostatin, cyclophosphamide, and rituximab in B-cell chronic lymphocytic leukemia. Invest New Drugs. 2011. [Epub ahead of print.]

120. Robak T, Smolewski P, Cebula B, Grzybowska-lzydorczyk O, Blonski JZ. Rituximab plus cladribine with or without cyclophosphamide in patients with relapsed or refractory chronic lymphocytic leukemia. Eur J Haematol. 2007;79(2):107-113.

121. Bowen DA, Call TG, Jenkins GD, et al. Methylprednisolone-rituximab is an effective salvage therapy for patients with relapsed chronic lymphocytic leukemia including those with unfavorable cytogenetic features. Leuk Lymphoma. 2007;48(12):2412-2417.

122. Castro JE, James DF, Sandoval-Sus JD, et al. Rituximab in combination with high-dose methylprednisolone for the treatment of chronic lymphocytic leukemia. Leukemia. 2009;23(10):1779-1789.

123. Fischer K, Cramer P, Busch R, et al. Bendamustine combined with rituximab in patients with relapsed and/or refractory chronic lymphocytic leukemia: a multicenter phase II trial of the German Chronic Lymphocytic Leukemia Study Group. J Clin Oncol. 2011; 29(26):3559-3566.

124. Fischer K, Cramer P, Stilgenbauer S, et al. Bendamustine combined with rituximab (BR) in first-line therapy of advanced CLL: a multicenter phase II trial of the German CLL Study Group (GCLLSG) [abstract]. Blood. 2009;114:89:205.

125. Nabhan C, Patton D, Gordon LI, et al. A pilot trial of rituximab and alemtuzumab combination therapy in patients with relapsed and/or refractory chronic lymphocytic leukemia (CLL). Leuk Lymphoma. 2004;45(11):2269-2273.

126. Zent CS, Call TG, Shanafelt TD, et al. Early treatment of high-risk chronic lymphocytic leukemia with alemtuzumab and rituximab. Cancer. 2008;113(8):2110-2118.

127. Faderl S, Ferrajoli A, Wierda W, et al. Alemtuzumab by continuous intravenous infusion followed by subcutaneous injection plus rituximab in the treatment of patients with chronic lymphocytic leukemia recurrence. Cancer. 2010;116(10):2360-2365.
128. Tadmor T, Polliack A. Rituximab in space: intrapleural and other novel routes of administration for lymphomas and lymphoid leukemias. Leuk Lymphoma. 2011. [Epub ahead of print.]

129. Keating M, O'Brien S. High-dose rituximab therapy in chronic lymphocytic leukemia. Semin Oncol. 2000;27(6 Suppl 12):86-90.

130. Aue G, Lindorfer MA, Beum PV, et al. Fractionated subcutaneous rituximab is well-tolerated and preserves CD20 expression on tumor cells in patients with chronic lymphocytic leukemia. Haematologica. 2010;95(2):329-332.

131. Williams ME, Densmore JJ, Pawluczkowycz AW, et al. Thrice-weekly low-dose rituximab decreases CD20 loss via shaving and promotes enhanced targeting in chronic lymphocytic leukemia. J Immunol. 2006; 177(10):7435-7443.

132. Rubenstein JL, Fridlyand J, Abrey L, et al. Phase I study of intraventricular administration of rituximab in patients with recurrent CNS and intraocular lymphoma. J Clin Oncol. 2007;25(11):1350-1356.

133. Jaime-Pérez JC, Rodríguez-Romo LN, González-Llano O. Effectiveness of intrathecal rituximab in patients with acute lymphoblastic leukaemia relapsed to the CNS and resistant to conventional therapy. Br J Haematol. 2009;144(5):794-795.

134. Schmidt HH, Renner H, Linkesch W. Intrapleural instillation of rituximab for the treatment of malignant pleural effusions in NHL. Haematologica. 2004;89(11):ECR39

135. Law MF, Yip SF, Poon WL, et al. Intrapleural rituximab for the treatment of malignant pleural effusion due to B-cell lymphomas. Leuk Lymphoma. 2011. [Epub ahead of print.]

136. Ng T, Pagliuca A, Mufti GJ. Intraperitoneal rituximab: an effective measure to control recurrent abdominal ascites due to non-Hodgkin's lymphoma. Ann Hematol. 2002;81(7):405-406.

137. Crysandt M, Neumann B, Das M. Intraperitoneal application of rituximab in refractory mantle cell lymphoma with massive ascites resulting in local and systemic response. Eur J Haematol. 2007; 79(6):546-549.

138. US Food and Drug Administration. FDA approves Rituxan to treat chronic lymphocytic leukemia. Available from: http://www.fda. gov/newsevents/newsroom/pressannouncements/ucm201069.htm. Accessed May 18, 2011.

139. Robak T, Robak E. New anti-CD20 monoclonal antibodies for the treatment of B-cell lymphoid malignancies. Bio Drugs. 2011; 25(1):13-25.

140. Robak T. Ofatumumab, a human monoclonal antibody for lymphoid malignancies and autoimmune disorders. Curr Opin Mol Ther. 2008; 10(3):294-309.

141. Robak T. GA-101, a third-generation, humanized and glyco-engineered anti-CD20 mAb for the treatment of B-cell lymphoid malignancies. Curr Opin Investig Drugs. 2009;10(6):588-596.

142. Eichhorst B, Dreyling M, Robak T, Montserrat E, Hallek M; ESMO Guidelines Working Group. Chronic lymphocytic leukemia: ESMO Clinical Practice Guidelines for diagnosis, treatment and follow-up. Ann Oncol. 2011;22 Suppl 6:vi50-54.

143. Dreyling M, Ghielmini M, Marcus R, Salles G, Vitolo U; ESMO Guidelines Working Group. Newly diagnosed and relapsed follicular lymphoma: ESMO Clinical Practice Guidelines for diagnosis, treatment and follow-up. Ann Oncol. 2011;22 Suppl 6:vi59-vi63.
Blood and Lymphatic Cancer: Targets and Therapy

\section{Publish your work in this journal}

Blood and Lymphatic Cancer: Targets and Therapy is an international, peer-reviewed, open access journal focusing on blood and lymphatic cancer research, identification of therapeutic targets and the optimal use of preventative and integrated treatment interventions to achieve improved outcomes, enhanced survival and quality of life for the

\section{Dovepress}

cancer patient. The manuscript management system is completely online and includes a very quick and fair peer-review system. Visit http://www.dovepress.com/testimonials.php to read real quotes from published authors. 